\title{
Review \\ Effect of Metal Nanopowders on the Performance of Solid Rocket Propellants: A Review
}

\author{
Weiqiang Pang ${ }^{1,2, * \mathbb{C}}$, Yang $\mathrm{Li}^{1}{ }^{1}$, Luigi T. DeLuca ${ }^{3}{ }^{\mathbb{D}}$, Daolun Liang ${ }^{4}$, Zhao Qin ${ }^{2}$, Xiaogang Liu ${ }^{1}$, Huixiang $\mathrm{Xu}^{1}$ \\ and Xuezhong Fan ${ }^{1}$ \\ 1 The Third Department, Xi'an Modern Chemistry Research Institute, Xi'an 710065, China; \\ yang12110420@163.com (Y.L.); liuxg88066@163.com (X.L.); xhx204@163.com (H.X.); \\ xuezhongfan@126.com (X.F.) \\ 2 Science and Technology on Combustion and Explosion Laboratory, Xi'an Modern Chemistry Research \\ Institute, Xi'an 710065, China; qzhao087@hotmail.com \\ 3 Space Propulsion Laboratory (SPLab), Politecnico di Milano, I-20156 Milan, Italy; luigi.t.deluca@gmail.com \\ 4 Key Laboratory of Energy Thermal Conversion and Control of Ministry of Education, School of Energy and \\ Environment, Southeast University, Nanjing 210096, China; ldl@seu.edu.cn \\ * Correspondence: nwpu_pwq@163.com; Tel.: +86-029-88291765
}

Citation: Pang, W.; Li, Y.; DeLuca, L.T.; Liang, D.; Qin, Z.; Liu, X.; Xu, H. Fan, X. Effect of Metal Nanopowders on the Performance of Solid Rocket Propellants: A Review. Nanomaterials 2021, 11, 2749. https://doi.org/ $10.3390 /$ nano11102749

Academic Editor: Detlef W. Bahnemann

Received: 16 September 2021

Accepted: 14 October 2021

Published: 17 October 2021

Publisher's Note: MDPI stays neutral with regard to jurisdictional claims in published maps and institutional affiliations.

Copyright: (c) 2021 by the authors. Licensee MDPI, Basel, Switzerland. This article is an open access article distributed under the terms and conditions of the Creative Commons Attribution (CC BY) license (https:/ / creativecommons.org/licenses/by/ $4.0 /)$.

\begin{abstract}
The effects of different types of nano-sized metal particles, such as aluminum (nAl), zirconium (nZr), titanium (nTi), and nickel (nNi), on the properties of a variety of solid rocket propellants (composite, fuel-rich, and composite modified double base (CMDB)) were analyzed and compared with those of propellants loaded with micro-sized $\mathrm{Al}(\mathrm{mAl})$ powder. Emphasis was placed on the investigation of burning rate, pressure exponent $(n)$, and hazardous properties, which control whether a propellant can be adopted in solid rocket motors. It was found that nano-sized additives can affect the combustion behavior and increase the burning rate of propellants. Compared with the corresponding micro-sized ones, the nano-sized particles promote higher impact sensitivity and friction sensitivity. In this paper, 101 references are enclosed.
\end{abstract}

Keywords: material chemistry; solid propellant; nano-sized metal particles; hazardous properties; combustion performance

\section{Introduction}

High-energy solid propellants play an essential role in propulsion for space exploration [1,2]. The specific impulse or density specific impulse of propellants can be increased by the inclusion of certain reactive metal powders, such as aluminum (Al), magnesium $(\mathrm{Mg})$, boron (B), etc. Metal particles with different grain sizes considerably influence the combustion and hazardous properties of solid rocket propellants: in particular, the burning rate was significantly enhanced by adding fractions of nano-sized particles, while the rheological performance of propellant slurry was significantly increased as well $[3,4]$. Several works on nano-sized metal powders were conducted worldwide, and many good achievements were obtained [5-8]. Replacement of micro-sized particles by nano-sized particles in the propellant composition is one of the most important aspects thanks to the excellent features of energetic nano-ingredients [9]. For example, the effect of Al particle size on the combustion performance of fuel-rich propellants with high $\mathrm{Al}$ content was studied. It was found that the presence of aluminum nanopowder (nAl) can evidently improve the combustion performance of propellants [10]. Compared with $\mathrm{mAl}, \mathrm{nAl}$ burns directly by single particles instead of melting followed by burning, which would decrease the diffusion length and shorten ignition time [11]. Meanwhile, the high surface energy of $\mathrm{nAl}$ particles may lead to the agglomeration of $\mathrm{Al}$, which not only inhibits the mass transfer and heat diffusion during the reaction, but also causes poor mechanical properties of the aluminized explosives [12,13]. The qualities of nAl (morphology, size distribution, 
and presence of alumina $\left.\left(\mathrm{Al}_{2} \mathrm{O}_{3}\right)\right)$ have an important effect on energy release [14]. To address these issues, several series of $\mathrm{nAl}$-based coated energetic materials, including Al@polyvinylidene fluoride (PVDF), Al@nitrocellulose (NC), and Al@ammonium perchlorate (AP)/NC, were fabricated via spray coating $[11,15]$, and a novel structure composed of energetic metal-organic frameworks (EMOFs) and polydopamine (PDA)-coated $\mathrm{Al}$ (nAl@PDA) was designed to develop energy-storage. The nAl surrounded by metal oxides was activated with self-sustained combustion with multi-level energy-release [16]. Recently, core-shell configuration was introduced to tune the microstructure of energetic composites, which has been demonstrated to be a highly effective strategy to obtain synergistic properties [17-19]. In a previous work, energetic polymer GAP was covalently grafted onto the nano-Al surface. The core-shell structured Al@GAP achieved water resistance, enhanced compatibility with polymeric binder, and enhanced combustion performance [20]. In this review, $\mathrm{nAl}$ coated with various materials are summarized, and the evaluation of active $\mathrm{Al}$ content (AAC) is carried out. The focus of this paper is on the combustion enhancement of different types of nano-sized metal particles, such as nAl, zirconium (nZr), titanium (nTi), nickel (nNi), etc., on solid propellants. The resulting properties are compared with those of propellants loaded with micro-sized $\mathrm{Al}(\mathrm{mAl})$ powder. The prospects and future trends of metal nanopowders were investigated, which could make the new propellants useable for solid rocket motor applications.

\section{Nano Al}

$\mathrm{nAl}$, as a new type of metal fuel, is often used as additive in solid propellants due to its unique properties, such as high energy density and low temperature oxidation performance, which can evidently improve the burning rate and possibly decrease the pressure exponent (n). For example, see [21,22]. Despite their advantages, such as large surface, small particle size, and high surface energy, $\mathrm{nAl}$ powders are easy to react with oxygen to form a dense oxide film $\left(\mathrm{Al}_{2} \mathrm{O}_{3}\right)$ when exposed to air. The $\mathrm{Al}_{2} \mathrm{O}_{3}$ formation will limit the application of $\mathrm{nAl}$ powders in rocket propellants and bring a certain degree of difficulty in storage [23]. Therefore, in order to maintain its activity and storage performance, it is necessary to improve the surface coating of nAl.

\subsection{Coating of $n A l$}

The materials for surface coating of $\mathrm{nAl}$ powders are mostly inorganic materials, organic materials, energetic materials (such as carbon, metal, and metal oxide coating), polymer coating, etc. Coating of nAl can form core-shell structures, and core-shell structured nano metals have gained considerable attention due to their improved material properties and combined multiple functionalities. Core-shell structured nano energetic materials mainly include core-shell structured explosives and metastable intermolecular complex (MICs). For core-shell explosives, the "shell" acts as a protective "coat" on sensitive explosives, making them more resistant to external stimuli such as high temperature, friction, impact, static electricity, and compression. For core-shell structured MICs, the fuel and oxidizer are like a well-matched "gear"; they have large and close contact with each other, so that the thermite reaction is easier and more complete than other structured MICs, resulting in increased heat output and improved reactivity. Figure 1 schematically illustrates the advantages of core-shell structured particles. 


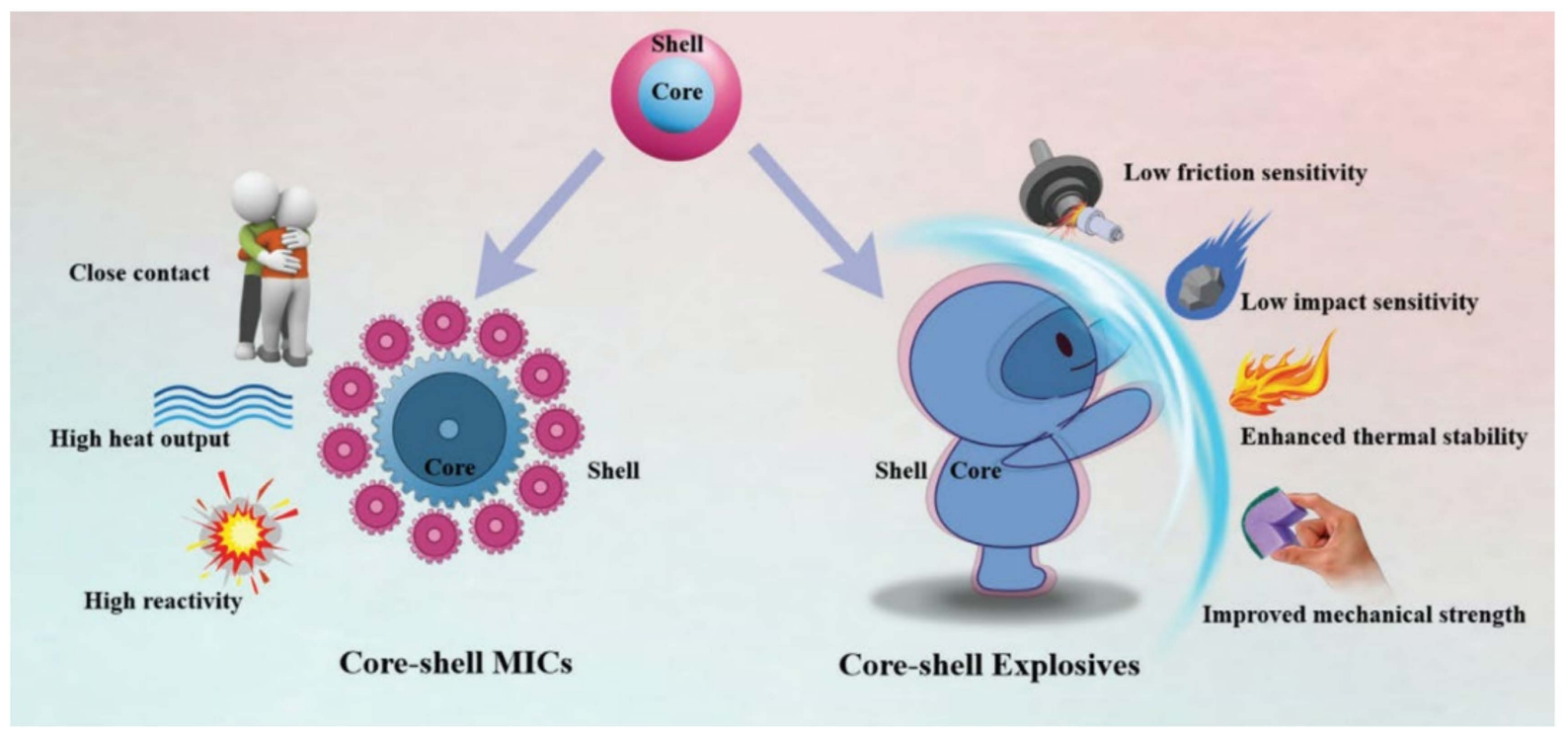

Figure 1. Schematic of core-shell structured nEMs advantages. Reproduced from [24], with permission from Wiley, 2020.

\subsubsection{Carbon Coating}

Carbon-coated nAl powder (nAl@C) was first used by Rouff [25]. Generally, carbon is stable at low temperatures, and it can be oxidized to $\mathrm{CO}_{2}$ at high temperatures without increasing the load of solid propellant. Thus, it is a good coating agent for nAl powders. For instance, one thin carbon coating using either a laser induced plasma or a DC plasma-arc was investigated, and the carbon coating was created by injecting ethylene $\left(\mathrm{C}_{2} \mathrm{H}_{4}\right)$ directly downstream of the plasma. The elemental composition of nAl@C was measured in real time with a recently developed quantitative single particle mass spectrometer (SPMS). It was found that the nAl@C features a layer of 1-3 nm thickness [26]. Another example is [27], wherenAl@C was prepared under a methane and Ar gas atmosphere using laser-induction complex heating method: a core-shell structure of nanoparticles with $20-40 \mathrm{~nm}$ diameters and 3-8 $\mathrm{nm}$ thickness was obtained.

\subsubsection{Metal Coating}

$\mathrm{nAl}$ can be coated with metals, such as $\mathrm{B}$, nickel $(\mathrm{Ni})$, etc. When $\mathrm{B}$ is used as the surface coating of $\mathrm{nAl}$, the gasification of metal particles can be promoted during the heating process, and an extra exothermic enthalpy of (2.1-4.1) $\mathrm{J} \mathrm{g}^{-1}$ can also be obtained [28]. For example, when $\mathrm{nAl}$ powder is coated with $\mathrm{B}(\mathrm{nAl} @ \mathrm{~B})$, the dispersion of $\mathrm{nAl} @ \mathrm{~B}$ improves, the onset oxygen temperature increases by $30-40^{\circ} \mathrm{C}$, and the heat of combustion of $\mathrm{Al}$ also increases due to the $\mathrm{AlB}_{2}$ coating layer. Moreover, the active $\mathrm{Al}$ content of nAl@B shows little change after storage in air with $70 \%$ humidity for one year [29].

When $\mathrm{nAl}$ is coated with $\mathrm{Ni}$, not only can the physicochemical properties of single $\mathrm{Al}$ particles be maintained, but the stability and dispersion of nAl powder can also be improved [30]. Moreover, it was found that Nican promote the oxidation of Al. For instance, a core-shell structured nAl@Ni particle was prepared using a displacement reaction method in $\mathrm{N}_{2}$ atmosphere for $12 \mathrm{~h}$ and $\mathrm{nAl}$ powder with $60-100 \mathrm{~nm}$ diameter as raw material. It was found that the stability of the resulting nAl@Ni particle was good. The active $\mathrm{Al}$ content changes little after storage for one month in air. Moreover, it can increase the burning rate of solid propellants when fractions of $\mathrm{Al}$ are replaced by nAl@Ni [31,32]. Furthermore, the Ni layer plays a crucial role in enhancing the oxidation of nA1 powders due to its oxygen transfer ability. For instance, nAl@Ni was prepared by a replacement reduction method, and a larger content of Ni powders further increases the weight growth rate of A1 powders. The ignition and combustion behaviors of composite powders were observed at $1000{ }^{\circ} \mathrm{C}$, when the covering content of Ni increased to $8.93 \%$ [33]. 


\subsubsection{Metal Oxide Coating}

The composite of $\mathrm{nAl}$ and metal oxide forms a kind of high reactive energetic material, which can reduce the agglomeration of particles and increase the burning rate of solid propellants as well. $\mathrm{Al}_{2} \mathrm{O}_{3}$ is one of this kind of metal oxides, because the coating process is simple, and only a small amount of air is needed to be filled to the stored nAl powder in an inert atmosphere. For instance, $\mathrm{nAl}$ powder was coated with $\mathrm{Al}_{2} \mathrm{O}_{3}\left(\mathrm{nAl} @ \mathrm{Al}_{2} \mathrm{O}_{3}\right)$, and particles with 2-5 $\mathrm{nm}$ coating thickness were obtained [34]. However, there are drawbacks, such as the $\mathrm{Al}_{2} \mathrm{O}_{3}$ layer can hinder the heat release behavior of $\mathrm{nAl}$ powder in the combustion process and even increase its oxidation exothermic temperature. Moreover, the active $\mathrm{Al}$ content could be reduced to $30-50 \%$ when the average diameter of nAl powder reaches 20-30 nm. Other coated particles, such as nAl@CuO, nAl@ $\mathrm{Fe}_{2} \mathrm{O}_{3}, \mathrm{nAl} @ \mathrm{Co}_{3} \mathrm{O}_{4}$, etc., with high reactivity and quick reactive speed were prepared as well [35-38].

\subsubsection{Organic Acid Coating}

As a kind of surface modifier, the carboxyl group of organic acid can not only react with $\mathrm{Al}$ to form a chemical bond, which can be firmly coated on the surface of nAl powder, but the carbon chain at the other end can also form a steric hindrance, improving the dispersion and protecting the activity of $\mathrm{nAl}$ powders. Moreover, organic acids can be used as a combustion agent to provide energy in the combustion of nAl powders [39]. For instance, oleic acid (OA, $\mathrm{C}_{18} \mathrm{H}_{36} \mathrm{O}_{2}$ ) was dissolved in ethanol to coat nAl (nAl@OA) with active $\mathrm{Al}$ content of $61.5 \%$ for $30 \mathrm{~nm}$ diameter particles, and the exothermic peak temperature moved forward to about $500^{\circ} \mathrm{C}$, while the thermal decomposition temperature of nAl@OA/hexogen (RDX) is lower than that of Al/OA/RDX mixture [40-42]. The effect of nAl@SA, formed with stearic acid (SA)-coated nAl, on the combustion characteristics of $\mathrm{nAl}$ were also studied. Results show that $\mathrm{nAl}$ particles disperse more evenly, the mass fraction of $\mathrm{Al}$ increases by $9.62 \%$, and the combustion of nAl@SA powder is more complete than that of $\mathrm{nAl}$ powder. In particular, the optimized mass proportion of SA and $\mathrm{Al}$ is 1:3 [43]. Meanwhile, nAl@OA and nAl@SA were suspended in kerosene and ethanol: it was found that $\mathrm{nAl}$ particles with a protecting surface reveal increased stability towards oxidation in air and in water during the storage period, showing for organic-coated metal particles the presence of two layers (an external organic layer and an internal oxide layer) $[44,45]$.

When perfluorooctanoic acid ( $\mathrm{PA}, \mathrm{C}_{17} \mathrm{H}_{35} \mathrm{COOH}$ ) was introduced to coat $n \mathrm{Al}$ by means of the electrical explosion of wires (EEW) method, it was found that the active Al content decreased from $79 \%$ to $59 \%$ after nAl@PA was stored for one year [46]. Furthermore, nAl was coated with paraffin and PA by liquid phase chemical method, producing spherical particles with coated $\mathrm{Al}$ diameter of $80-120 \mathrm{~nm}$ and active $\mathrm{Al}$ content of $80.8 \%$ [21]. Additionally, nAl powder was coated with perfluorotetradecanoic acid (FS) to form nAl@FS under nitrogen atmosphere: it was found that the dispersity of nAl@FS was improved, and the particle size distribution was more homogeneous. Compared with nAl powders, the ignition delay time of nAl@FS is shorter under the same laser heat flux density. The combustion reaction of nAl@FS is more intense while the flame brightness is higher in the laser ignition process. During the combustion of nAl@FS at low pressures, the flame is more intense, and the flame brightness is higher [47]. In another example, the electric spark ignition for a cloud of $\mathrm{nAl}$ powder formed in a combustion tube was used to measure comparative flame front propagation velocities with different $\mathrm{Al}$ particle sizes with and without organic coating. The results show that $\mathrm{nAl}$ particle clouds burn faster than $\mathrm{mAl}$ particle clouds. Reducing the size of particles from micro-scale to nano-scale reduces the ignition and burning times significantly and increases the particle cloud flame propagation velocity [48].

\subsubsection{Polymer Coating}

A binder used to coat $\mathrm{nAl}$ powder can isolate the contact between $\mathrm{nAl}$ and air. In recent years, NC and azide binder with high energy have become very popular energetic materials. 
To prevent further oxidation and inactivation in the air, nAl powders were pretreated with silane coupling agents and then coated with glycidyl azide polymer (GAP) under nitrogen atmosphere, and thus GAP-coated nAl (nAl@GAP) was obtained [49]. The results show that the coupling agent plays a role as a bridge between GAP and nAl: the core-shell particles are observed, the stability in hot water and energy releasing performance of $n A l$ improve with the assistance of GAP, and the thickness of the GAP shell layer could be tuned by changing the relative ratio of reactants [20,50]. WhilenAl and nAl@GAP have little influence on the liquefaction temperature of $\mathrm{ADN}$, the decomposition temperature increases significantly. Several nAl coatings with polymer make the activation energy of $\mathrm{nAl}$ increase slightly, while it has little influence on the combustion of propellant strands and solid motor charges. For instance, hydroxyl terminated polybutadiene (HTPB) was used to coat nAl to form nAl@HTPB. When HTPB coating ratio was $21.6 \%$, the exothermic heat of $\mathrm{Al}$ in the sample is $4.954 \mathrm{~kJ} \cdot \mathrm{g}^{-1}$, the active $\mathrm{Al}$ content is less than $50 \%$, and the activation energy is $253.21 \mathrm{~kJ} \cdot \mathrm{mol}^{-1}$ [51].

Being NC a very important energetic binder in explosives, $\mathrm{nAl}$ powders were coated with it (nAl@NC), and the performance was compared with that of nAl@OA (oleic acid, $\mathrm{C}_{17} \mathrm{H}_{33} \mathrm{COOH}$ ), nAl@SA (stearic acid, $\mathrm{C}_{17} \mathrm{H}_{35} \mathrm{COOH}$ ), and non-coated particles. It was found that the surface protection of $\mathrm{nAl}$ powders by the above chemical origin coatings leads to some advantages in practical applications of energetic systems (Figure 2). In fact, $\mathrm{nAl}$ powders with a protected surface show an increased stability to oxidation in air during the storage period and higher reactivity under heating [52]. By using a mechanical chemistry method, it was also found for Al coated with NC and TNT that nAl@NC+TNT has high thermal reaction characteristics. When coated particles were added to the RDX/paraffin/Al with 76/4/20 mass ratio, the activation energy, impact sensitivity, and heat of explosion increased by $8.5 \%, 9.1 \%$, and $6.48 \%$, respectively, while the friction sensitivity decreased by $2.4 \%$.
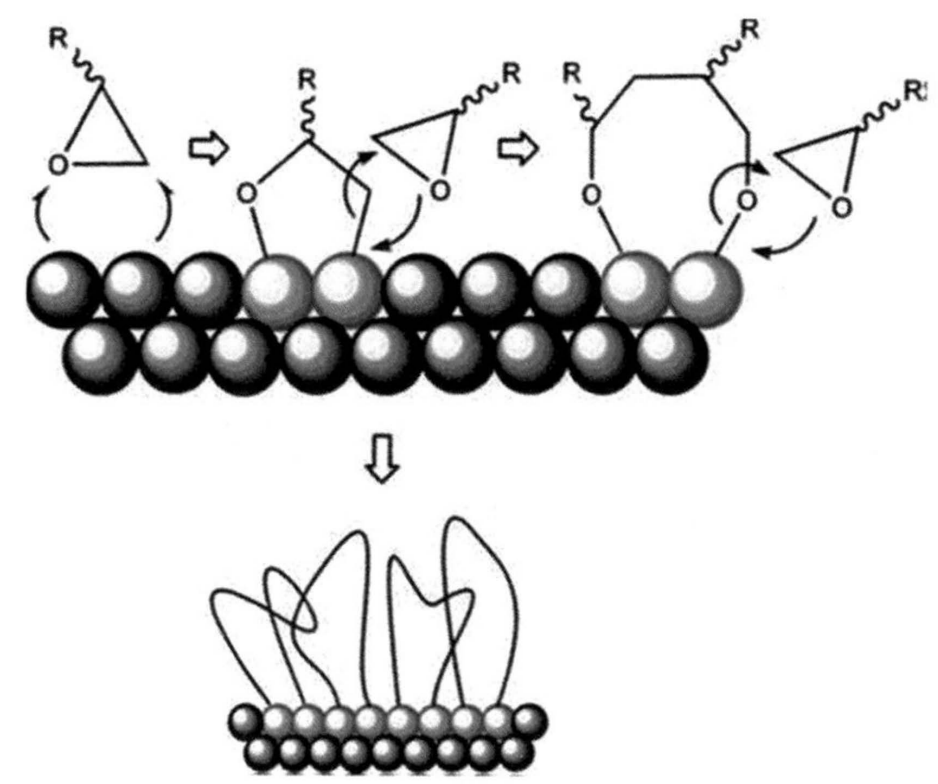

Figure 2. Schematic diagram of nAl powder coated with epoxy compound. Reproduced from [23], with permission from Applied Surface Science, 2007.

\subsubsection{Energetic Materials Coating}

RDX, which has the advantages of high specific impulse and low combustion temperature, is the main nitramine filler in solid propellants. RDX-coated nAl powder (nAl@RDX) can improve the performance of $\mathrm{Al}$ powder in solid propellants and reduce the activation energy. For instance, $\mathrm{nAl}$ coated with RDX particles were prepared using a solventantisolvent method with $\mathrm{N}, \mathrm{N}$-methylformamide (DMF) and toluene as the solvents. It was 
found that the active $\mathrm{Al}$ content of nAl@RDX (89\%) is higher than that of $\mathrm{Al} / \mathrm{RDX}$ mixture $(66 \%)$. Moreover, the initial decomposition temperature of RDX decreased by $45 \mathrm{~K}$ by the catalysis of $\mathrm{nAl}[53]$.

\subsubsection{Fluoride Coating}

Based on theoretical calculations, fluorine was proposed as an additional oxidizer to change the reaction rates and $\mathrm{Al}$ combustion mechanisms. A typical preparation process is shown in Figure 3 [54]. It was found that the underwater explosion energy increases with increasing fluorine content in the binder, while it decreases with increasing binder content [55]. Thus, nAl powders prepared by EEW method were coated with 5\%, 10\%, and $15 \%$ of fluororubber (nAl@F). Results show that the specific surface area of the nAl@F powders is slightly larger than that of the passivated nAl powders, while the active $\mathrm{Al}$ content is up to $85.85 \%$. Fluororubber coatings chemically adsorb on the surface of nAl powder, which enhances the thermal stability of $\mathrm{nAl}$ and prevents further oxidation. The fluororubber also promotes the combustion of nAl powders, and the heat of combustion of the $\mathrm{nAl} @ \mathrm{~F}$ is higher than that of $\mathrm{nAl}$ powders.

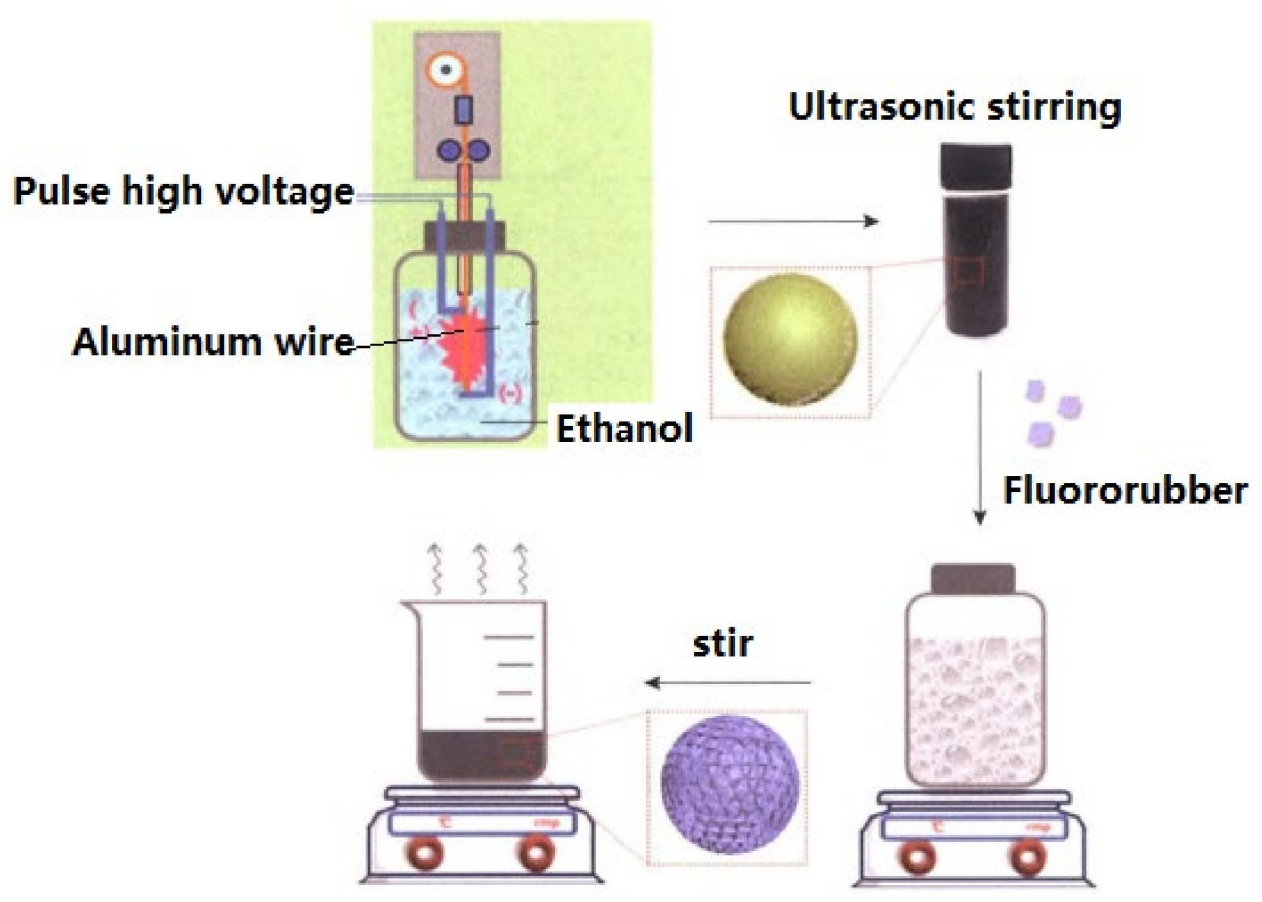

Figure 3. Preparation process of coated nAl powders. Reproduced from [56] with permission from Acta Armamentarii, 2019.

The effect of nAl@F on the combustion properties of HTPB-based fuels was also investigated [57]. The results showed that $\mathrm{nAl@F}$ powder has a certain promoting effect on the regression rate of the fuel, and this effect is independent of the oxidizer mass flux. The regression rate of the fuel with nAl@F is 13\% higher than that of the fuel without $\mathrm{nAl} @ \mathrm{~F}$ over the oxygen mass flux range of $100-380 \mathrm{~kg} \cdot \mathrm{m}^{-2} \cdot \mathrm{s}^{-1}$. In another instance, the effect of morphology, structure, and active $\mathrm{Al}$ content of the coated $\mathrm{nAl}$ particles with phenolic resin (PF), fluororubber (Viton B), and shellac through a solvent/nonsolvent method were investigated. The results indicated that the coated nAl particles have coreshell structures, and the thickness of the coating film is $5-15 \mathrm{~nm}$. Viton B coating has a much better protective effect by the active $\mathrm{Al}$ content. The energy amount and energy release rate of nAl@PF, nAl@Viton B, and nAl@shellac particles were larger than those of the raw nAl [58]. 


\subsubsection{Other Materials Coating}

In some cases, propellant ingredients were used as coating materials: under these circumstances, the ignition temperature could be reduced, and the heat release could be enhanced. For example, AP is a strong oxidant, which is commonly used in solid propellants or explosives. For AP-coated nAl (nAl@AP) obtained using recrystallization method, the ignition temperature of $\mathrm{nAl} @ \mathrm{AP}$ was less than that of $\mathrm{nAl}$ at a heating rate of $20^{\circ} \mathrm{C} \cdot \mathrm{min}^{-1}$. In particular, for nAl@AP with $10 \%$ and $15 \%$ of AP, the ignition temperatures decreased by about $200{ }^{\circ} \mathrm{C}$, which is due to the rapid decomposition of $\mathrm{AP}$, and has an obvious effect on $\mathrm{nAl}$ ignition $[59,60]$. Dioctyl sebacate (DOS) is another common ingredient of propellant: when DOS coating ratio is $29.8 \%$, the exothermic heat of $\mathrm{Al}$ in the sample is $4.955 \mathrm{~kJ} \cdot \mathrm{g}^{-1}$, while the active $\mathrm{Al}$ content is $75.6 \%$ [61]. When the mass concentration of dopamine (DA) is $3.5 \mathrm{~g} \cdot \mathrm{L}^{-1}$, DA can be polymerized into a firm PDA coating on the surface of nAl (nAl@PDA), and the crystal form of $\mathrm{Al}$ remains unchanged before and after coating [62].

The effect of differently coated nAl (including nAl@NDZ with $5 \%$ of NDZ, nAl@NGTC with $5 \%$ of NGTC, $\mathrm{nAl} @$ polymer with $50 \%$ of polymer, and $\mathrm{nAl} @ \mathrm{Al}_{2} \mathrm{O}_{3}$ with $1 \%$ of $\mathrm{Al}_{2} \mathrm{O}_{3}$ ) on the combustion performance of composite propellant $\mathrm{AP} / \mathrm{Al} / \mathrm{HTPB}=70 / 15 / 15$, with $5 \%$ of $\mathrm{mAl}$ replaced by $\mathrm{nAl}$ ) were investigated [63]. It was found that the active $\mathrm{Al}$ content and heat of explosive decreased from $95.33 \%$ and $5540.9 \mathrm{~J} \cdot \mathrm{g}^{-1}$ of $\mathrm{mAl}$ to $55.74-67.38 \%$ and $4388.7-4784.3 \mathrm{~J} \cdot \mathrm{g}^{-1}$ of $\mathrm{nAl}$, respectively. However, the burning rate at $7 \mathrm{MPa}$ increased from $9.31 \mathrm{~mm} \cdot \mathrm{s}^{-1}$ to $10.79 \mathrm{~mm} \cdot \mathrm{s}^{-1}$, while the pressure exponent decreased from 0.48 to 0.22 . It can be concluded that the addition of $\mathrm{nAl}$ is beneficial to improve the burning rate and possibly reduce the burning rate pressure exponent, but at the same time, the low active $\mathrm{Al}$ content of $\mathrm{nAl}$ powder leads to a reduction in the propellant explosive heat. This is in broad agreement with [22].

\subsection{Evaluation of Active Aluminum Content (AAC)}

Adding an appropriate amount of $\mathrm{nAl}$ powder can significantly improve the performance of solid propellants. However, due to the small size and surface effect of nAl powder, its reactivity is very high. Once $\mathrm{nAl}$ is prepared, the surface atoms will be oxidized, resulting in a reduction in $\mathrm{Al}$ content. Therefore, research on $\mathrm{nAl}$ powder reactivity, that is, how to maintain or control its reactivity, is of great significance to researchers worldwide. At present, the commonly used determination methods of elemental Al content mainly include gas volumetric method [64,65], redox titration method [66], thermogravimetric analysis method [67], and transmission electron microscopy method [68]. Taking transmission electron microscopy (TEM) as an example, this method first assumes that the structure of $\mathrm{nAl}$ powder is spherical and then uses high-resolution transmission electron microscope photos to evaluate the average particle size and oxide layer thickness of nAl particles through proportion calculation, as shown in Figure 4. The Al content of nAl powder is obtained from Equation (1) $[69,70]$ as

$$
C_{A l}=\frac{\rho_{A l} \cdot(D-2 t)^{3}}{\rho_{A l} \cdot(D-2 t)^{3}+\rho_{A l 2 O 3} \cdot\left[D^{3}-(D-2 t)^{3}\right]} \times 100 \%,
$$

where, $D$ is the average size of $n A l$ particles including the oxide layer; $t$ is the oxide layer thickness; and $\rho_{A l}$ and $\rho_{A l 2 O 3}$ are the density of $\mathrm{Al}$ and $\mathrm{Al}_{2} \mathrm{O}_{3}$, respectively. 

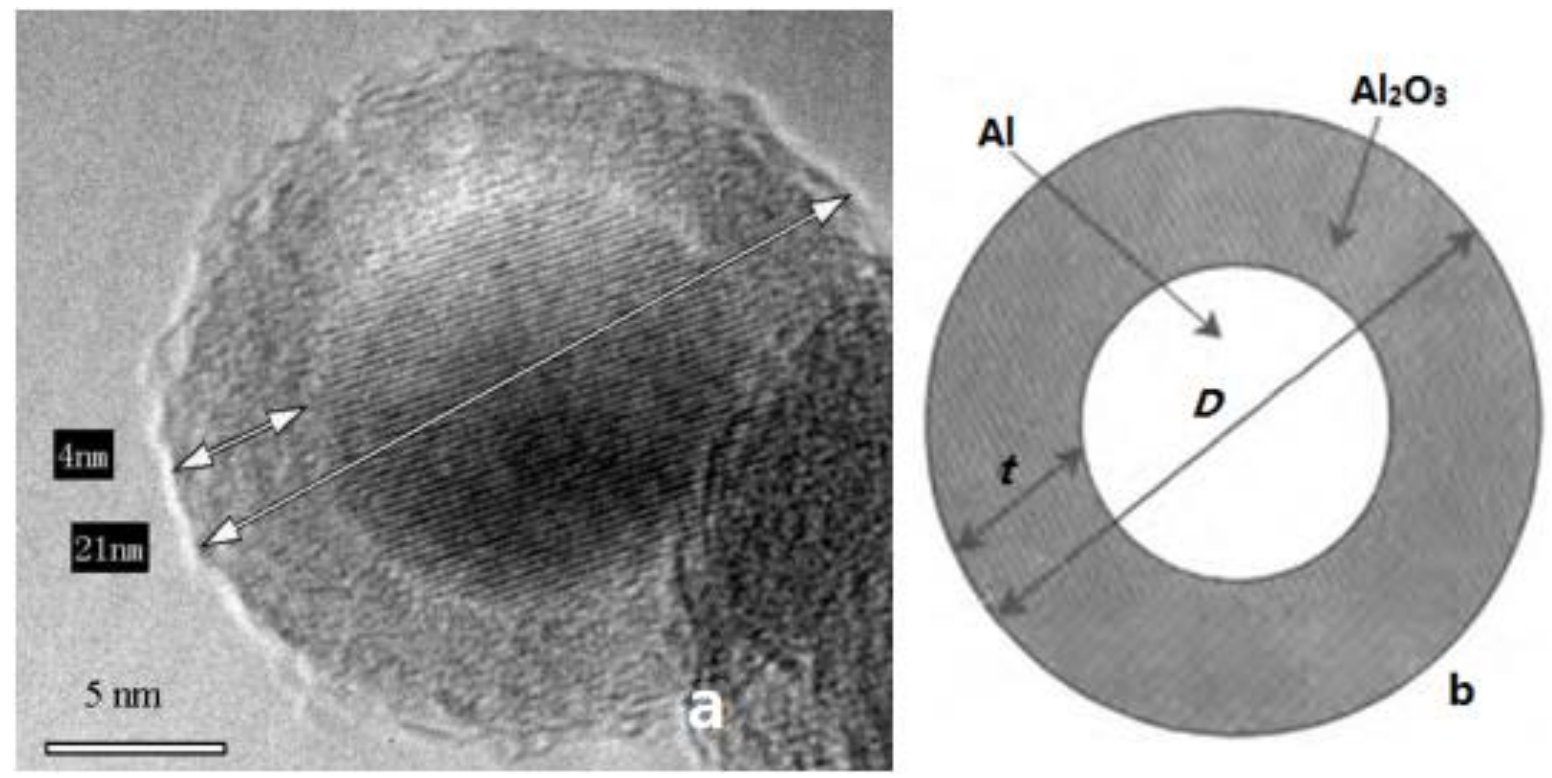

Figure 4. Images of $\mathrm{nAl}$ : (a) high resolution TEM image of nAl; (b) structure diagram of nAl powder. Reproduced from [71] with permission from Huazhong University of Science and Technology, 2008.

In addition, the relationships between particle size and active Al content (Figure $5 \mathrm{a}$ ) as well as particle size and oxide layer thickness (Figure $5 b$ ) were obtained. When the particle size is less than $70 \mathrm{~nm}$, the oxide thickness remains basically unchanged, and the particle size is less affecting the oxide thickness of $\mathrm{Al}$ powder. When the particle size of $\mathrm{Al}$ powder exceeds $70 \mathrm{~nm}$, the oxide layer thickness increases rapidly. At this time, the increase in particle size plays a decisive role in the oxide layer thickness of $\mathrm{Al}$ powder. This finding indicates that there is a lower limit on the thickness of $\mathrm{nAl}$ oxide film [72].


Figure 5. Curve of active $\mathrm{Al}$ content and oxide film thickness vs. diameter of $\mathrm{nAl}$ powder. (a): Active $\mathrm{Al}$ content vs. $\mathrm{nAl}$ diameter; (b): Oxide film thickness vs. nAl diameter. Reproduced from [72] with permission from Chinese Journal of Explosives and Propellants (Huo Zha Yao Xue Bao), 2011.

Furthermore, with decreasing nAl particle size, the oxidation initial temperature decreases, but the oxidation heat release shows a downward trend [32,73]. For example, the relationship between active $\mathrm{Al}$ content, particle size, and oxide layer was studied in [74]; see Figure 6. It was found that, when the nAl particle size is less than $100 \mathrm{~nm}$, the activity decreases sharply and the proportion of oxide layer increases. When the nAl particle size is $10 \mathrm{~nm}$, the AAC is only $30 \%$ and grows to about $30-50 \%$ when the particle diameter increases to $20 \mathrm{~nm}-30 \mathrm{~nm}$. When the particle size of Al powder is greater than $200 \mathrm{~nm}$, 
the AAC remains at $90 \%$. With the increase in particle size, the thickness of oxide layer continues to increase, but the activity is not significantly improved. It can be seen that, for particle diameter around $100 \mathrm{~nm}$, the $\mathrm{nAl}$ powder is relatively stable, and the $\mathrm{Al}$ content is high.

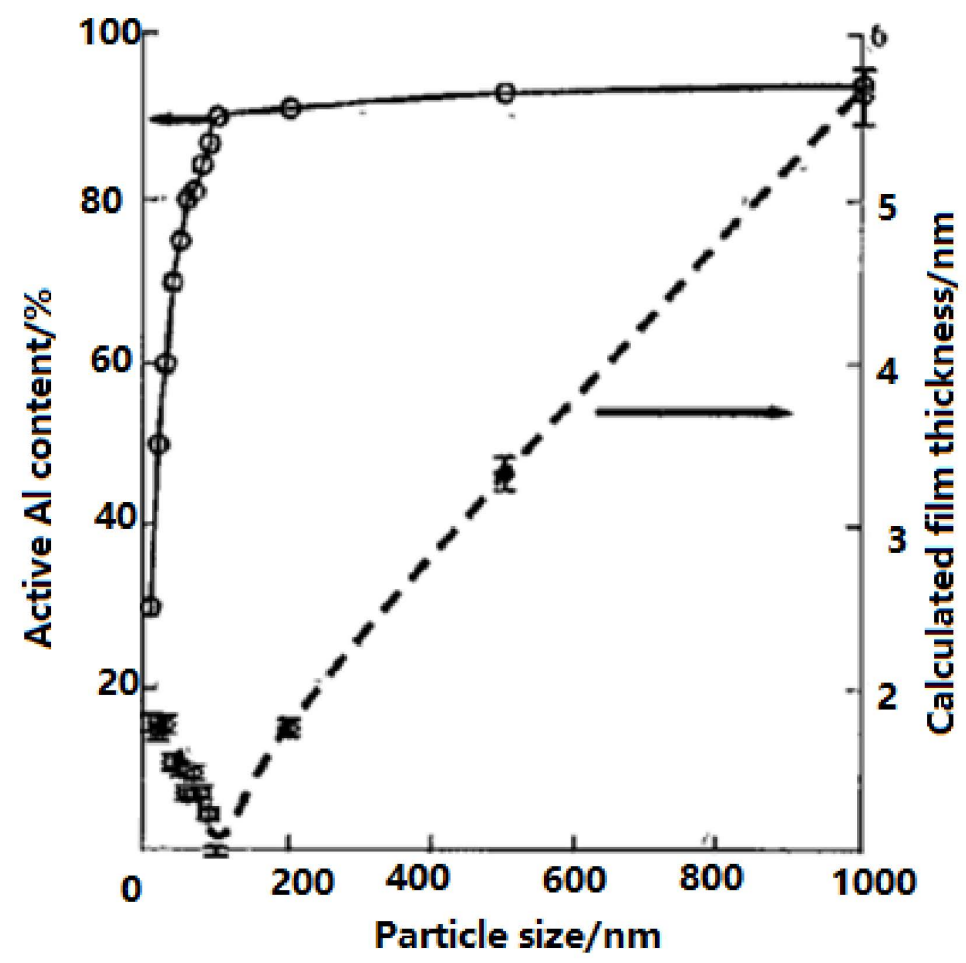

Figure 6. Relationships between active $\mathrm{Al}$ content and calculated oxide layer thickness vs. particle size. Reproduced from [74] with permission from Russian Journal of Physical Chemistry B, 2010.

Based on the coating of nAl with different materials and contents, the active $\mathrm{Al}$ content would be influenced by the coating layer. For example, the thermal properties of several kinds of nAl coated with polymer of different shell and thickness were studied by TG-DSC. The shell's effect on the reactivity of $\mathrm{nAl}$ was analyzed [75]. The results show that, for $\mathrm{nAl}$ with the same particle size, the thicker the shell is, the more weight the particle loses before oxidation and the less weight the particle gains during oxidation. From $520^{\circ} \mathrm{C}$ to $800{ }^{\circ} \mathrm{C}$, $50 \mathrm{~nm} \mathrm{Al}$ powder with $10 \%$ and $30 \%$ polymer coating gains $23.5 \%$ and $17.4 \%$, respectively. Additionally, Al powder with $100 \mathrm{~nm}$ diameter coated by $5 \%$ and $10 \%$ polymer increases $42.5 \%$ and $36.5 \%$, respectively. The energy release for $50 \mathrm{~nm} \mathrm{Al}$ powder is quicker than that of $100 \mathrm{~nm} \mathrm{Al}$. Al powder of $50 \mathrm{~nm}$ reaches the max oxidation rate at $550{ }^{\circ} \mathrm{C}$, much lower than that of $100 \mathrm{~nm} \mathrm{Al}$ powder $\left(590^{\circ} \mathrm{C}\right)$, but the reactivity of $50 \mathrm{~nm} \mathrm{Al}$ powder is lower than that of $100 \mathrm{~nm}$ Al powder (Figure 7). 

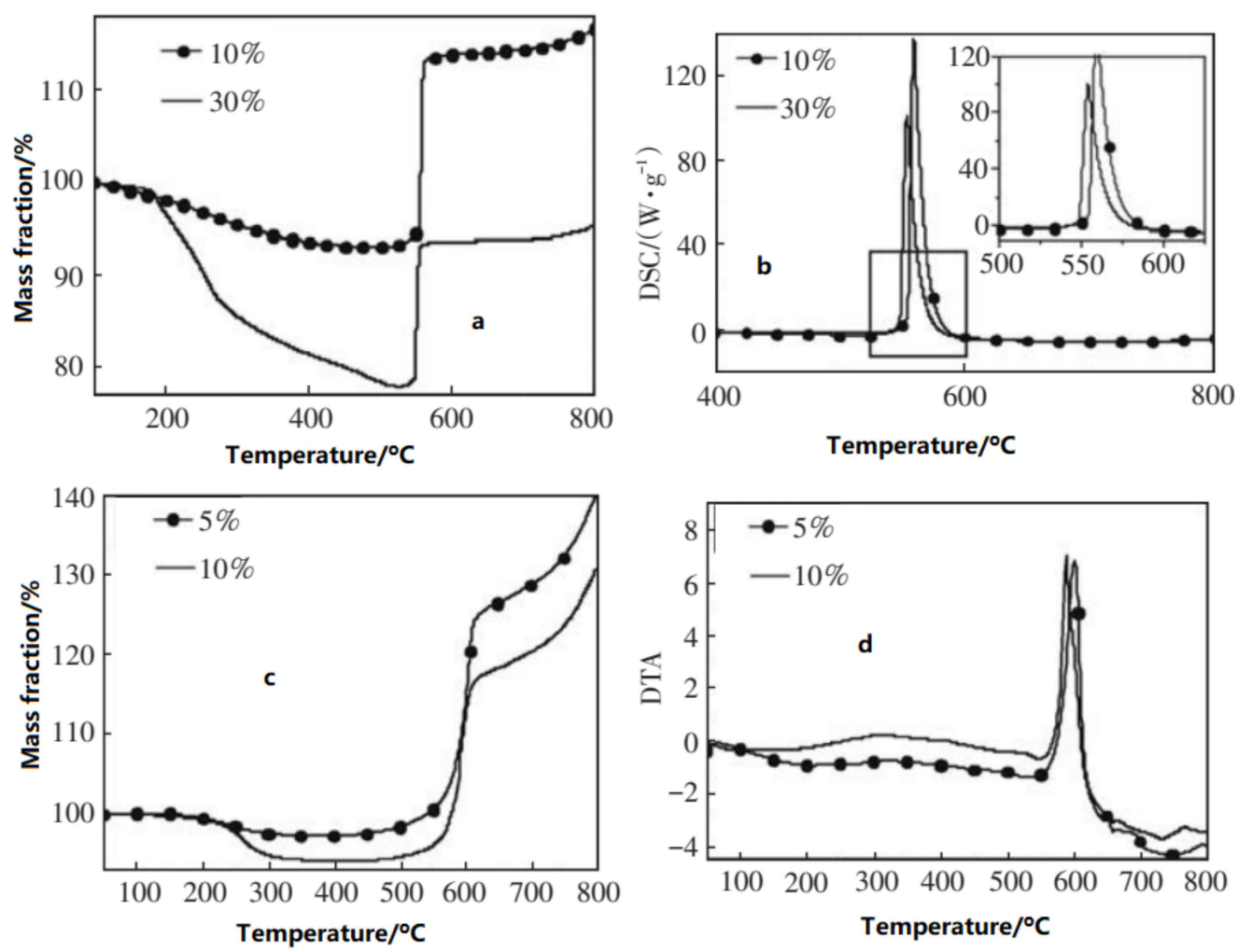

Figure 7. TG-DTA curves of $\mathrm{nAl}$ powder with different mass fraction of coating. (a): $10 \%$ and $30 \%$ coating with $50 \mathrm{~nm}$; (b): 5\% and 10\% coating with $100 \mathrm{~nm}$; (c): Mass fraction of TG curves; (d): DTA curves. Reproduced from [76], with permission from Journal of Solid Rocket Technology (Gu Ti Huo Jian Ji Shu), 2011.

Additionally, the long-term storage stability and self-activation reaction capability of nAl coated with $1 \mathrm{H}, 1 \mathrm{H}, 2 \mathrm{H}, 2 \mathrm{H}$-perfluorodecyltriethoxysilane (FAS-17) were studied. In terms of energetic performance, compared to the two-step slow oxidation of $\mathrm{nAl}$, the heatrelease rate of nAl@FAS-17 is significantly enhanced, resulting in a drastic oxidation process profiting from the surface reaction between the FAS- 17 and $\mathrm{Al}_{2} \mathrm{O}_{3}$ layer. More importantly, the ignition and combustion properties of nAl@FAS-17 are also greatly improved, which can undergo self-propagation combustion with a fairly high energy output even after storage in water [77].

\subsection{Combustion Enhancement of $n A l$ on Solid Propellants}

The burning rate of propellant determines the rate of gas generation, which determines the pressure inside the motor and the overall thrust [21]. Various factors such as the particle diameter, oxidizing species, pressure, and temperature affect the burning rate of the particles [78,79]. It was reported [80] that the initial oxidation temperature of $\mathrm{nAl}$ is much lower than that of $\mathrm{mAl}$ powder and the mass increment for $\mathrm{nAl}$ is higher than that of $\mathrm{mAl}$ at each oxidation stage, which may be attributed to the smaller particle size and larger specific surface area of $\mathrm{nAl}$ compared to that of $\mathrm{mAl}$ powder. The burning rate of $\mathrm{nAl}$ powder itself is higher than that of $\mathrm{mAl}$ powder, the ignition threshold of $\mathrm{nAl}$ is lower than that of $\mathrm{mAl}$ powder, and the difference increases with decreasing $\mathrm{nAl}$ particle size [22].

Moreover, the ignition temperature of $\mathrm{nAl}$ is lower and reactivity is higher than that of micro-sized Al. On one hand, the lower ignition temperature can make nAl powder oxidized and release heat over the low temperature range of $500-600{ }^{\circ} \mathrm{C}$. On the other hand, the higher reactivity of $\mathrm{nAl}$ can shorten the ignition delay and combustion time, and the particle size of condensed combustion products (CCPs) is small, and there is much heat feedback to the propellant burning surface [81]. 


\subsection{1. nAl Effects on the Combustion Performance of HTPB-Based Composite Propellants}

The effects of coated $\mathrm{nAl}(20-50 \mathrm{~nm})$ on the burning rate and pressure exponent of $\mathrm{HTPB}$ composite propellants ( $\mathrm{HTPB} / \mathrm{AP} / \mathrm{Al}=14.5 / 65.5 / 20)$ have been investigated; $3 \%$, $6 \%$, and $9 \%$ mass fraction of $\mathrm{mAl}$ were replaced by coated $\mathrm{nAl}$ and compared with that of $\mathrm{mAl}$ powder. The results show that the burning rates of propellants increase as $\mathrm{nAl}$ content increases, but the pressure exponents over the pressure range of 3-7 MPa decrease. Compared with propellant containing $\mathrm{mAl}$, the increments of burning rates of propellants containing $\mathrm{nAl}$ powder reduce gradually with increasing pressure due to the combustion characteristics and ignition performance differences of $\mathrm{nAl}$ and $\mathrm{mAl}$ powder [82]. Meantime, the combustion features of $85 \%$ bimodal HTPB / AP/Al composite propellant with $0.75 \%$ by mass of $\mathrm{nAl}$ into wet-mixed boron at varying ratios of $\mathrm{Al}$ to boron $(4: 1,2: 3,1: 4)$ were performed between 3.45 and $15.51 \mathrm{MPa}$ in a constant volume pressure vessel using nichrome wire ignition and compared to that of formulations with dry magnesium-boron $(\mathrm{MgB})$ and $\mathrm{mAl} @ \mathrm{~B}$ at the same mass loadings. Results showed the dry-powder nAl with wet-mixed boron and $\mathrm{MgB}$ formulations produced modest increases in burning rates compared to the composition without metals. The most promising formulation in terms of burning rate improvement was the $0.15 \%$ boron and $0.60 \%$ Al-coated particles, which increased the burning rates by $54 \%$ [83].

Furthermore, the $\mathrm{nAl}$ effects on the performance of fuel-rich propellant $(\mathrm{HTPB} / \mathrm{Al} / \mathrm{Mg}$ / $\mathrm{AP} /$ additives in the mass ratio $22 / 20 / 21 / 35 / 2$ ) were investigated. The burning rate and pressure exponent of the propellants with and without nAl particles were obtained under different pressures for a series of formulations over the range 0-20\% nAl. It was found [22] that the burning rates of fuel-rich solid propellants increase with increasing pressure, and the increase in extent over the pressure range 0.5-1 MPa is higher than that over the pressure range 2-3 MPa. The burning rate increases by $77 \%$ for fuel-rich propellant loaded with $20 \%$ of nAl powder at $1 \mathrm{MPa}$. The propellant pressure exponent increases a little for increasing mass fraction of $\mathrm{nAl}$ powder over the explored pressure range. By comparison, the pressure exponent of the formulation without $n A l$ is $0.38(0.5-3 \mathrm{MPa})$, which is the lowest one in the tested series.

Additionally, the densities and heat of combustion of fuel-rich propellants were measured and compared with the theoretical data. The density of fuel-rich solid propellants with different $\mathrm{nAl}$ mass fraction is in the range $1.627-1.636 \mathrm{~g} \cdot \mathrm{cm}^{-3}$, which is lower than that of the propellant with $\mathrm{mAl}$ powder $\left(1.641 \mathrm{~g} \cdot \mathrm{cm}^{-3}\right)$. The measured heat of combustion of fuel-rich propellant increases a little when a given mass fraction of $\mathrm{mAl}$ is replaced by $\mathrm{nAl}$ in the formulation, indicating that the combustion efficiency of nAl powder is higher than that of the $\mathrm{mAl}$ to some extent. At the same time, it was also found that the friction sensitivity and impact sensitivity of fuel-rich propellant increase with increasing mass fraction of $\mathrm{nAl}$ powder: the increasing slope of samples with $\mathrm{nAl}$ powder over the range $0-5 \%$ mass fraction is much higher than that of the remaining $5-20 \%$ interval, while the impact sensitivity of samples decreases significantly when the $\mathrm{nAl}$ mass fraction falls in the same interval 5-20\% [84].

\subsection{2. $\mathrm{nAl}$ Effects on the Combustion Performance of NEPE Propellants}

The effect of $\mathrm{nAl}$ particles on the combustion performance and heat of explosion of NEPE solid propellants (PET/NG+TEGDN/AP/HMX/Al = 7/18/35/35/5 in mass fraction) is presented in Figure 8. Compared to $\mathrm{mAl}$ particles, $\mathrm{nAl}$ particles show the advantages such as high reactivity, low ignition energy, and strong heat feedback to the propellant combustion surface, which increase the burning rate significantly by $1.5-2$ times (1-20 MPa), while the pressure exponent first increases from 0.57 to 0.68 (1-10 MPa) and then decreases 0.75 to 0.49 (10-20 MPa). It was also observed that the flame appears slightly dark for NEPE propellant with $5 \%$ mass fraction of mAl particles at $1 \mathrm{MPa}$, with a few bright lights during the combustion process, which are attributed to the presence of $\mathrm{Al}$ powder. The flame height increases with increasing $\mathrm{nAl}$ mass fraction, and it is the highest for $5 \% \mathrm{nAl}$. When the pressure increases to $3 \mathrm{MPa}$, the combustion is more vigorous, the 
dark area disappears, and the flame spits out from the burning surface. Meantime, the heat of explosion of NEPE solid propellants does not show much change with increasing $\mathrm{nAl}$ mass fraction in the formulation. The heat of explosion of the sample with $5 \% \mathrm{mAl}$ replaced by $\mathrm{nAl}$ is similar to that without $\mathrm{nAl}$.

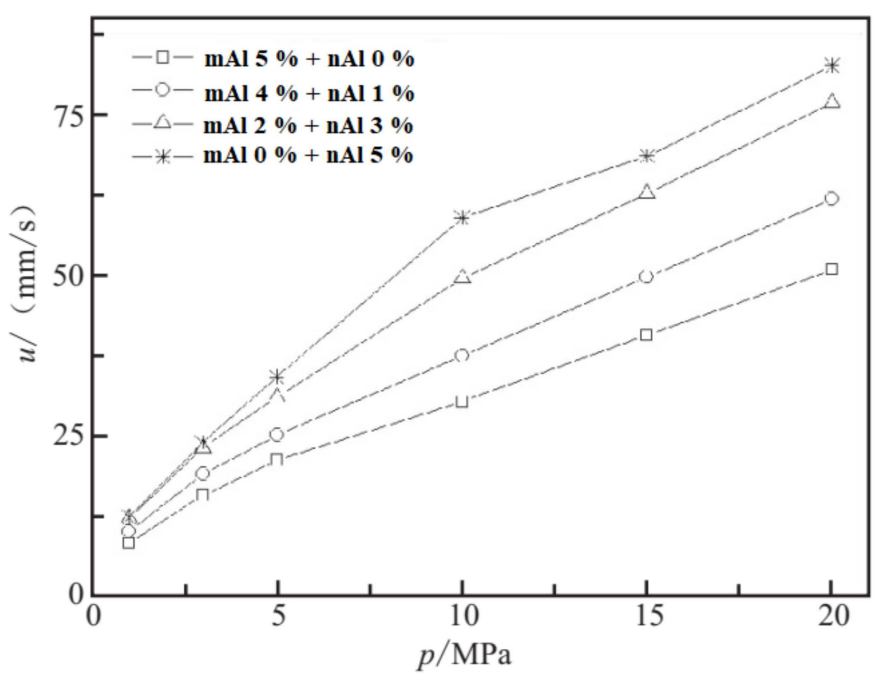

Figure 8. Effect of $\mathrm{nAl}$ and $\mathrm{mAl}$ on the combustion performance of NEPE propellants. Reproduced from [85] with permission from Journal of Solid Rocket Technology (Gu Ti Huo Jian Ji Shu), 2014.

\subsection{3. $\mathrm{nAl}$ Effects on the Combustion Performance of CMDB Propellants}

The effects of nano-sized composite, such as nano composites DPN (nDPN), nano-AlN (nAlN), and $\mathrm{nAl}$ on the combustion properties of DB propellant, CMDB propellant with RDX, and CMDB propellant with HMX/Al, are shown in Figure 9. It can be found that the burning rate of formulation with $0.5 \%$ mass fraction of $\mathrm{nAl}$ at $2-12 \mathrm{MPa}$ is higher than that of formulation without nAl. With the increase in the content of $\mathrm{nAl}$, the burning rate of propellant increases, which may be because the heat feedback from the flame increases with an increase in the $\mathrm{nAl}$ content. Meanwhile, the pressure exponent is low over the pressure range of $8-20 \mathrm{MPa}$. Compared with the same content $(1.5 \%)$ of $\mathrm{mAl}$, the burning rate of the propellant increases significantly, which may be due to the higher heat feedback of $\mathrm{nAl}$ with respect to $\mathrm{mAl}$ powder (Figure $9 \mathrm{a}$ ).

When nAlN was used to replace $\mathrm{Al}_{2} \mathrm{O}_{3}$, the propellant burning rate at 5-15 $\mathrm{MPa}$ decreased by an average of $2 \mathrm{~mm} \cdot \mathrm{s}^{-1}$. The burning rate of the formulation with $1.3 \%$ of $\mathrm{nAlN}$ at $18 \mathrm{MPa}$ was higher than that without nAlN, and the pressure exponent over the pressure range of 5-18 MPa was higher than that of nAlN. The burning rate of propellant with $2.6 \%$ of nAlN decreased by an average of $5 \mathrm{~mm} \cdot \mathrm{s}^{-1}$, while the pressure exponent increased (Figure 9b). Therefore, nAlN looks a good burning rate reducer, which can decrease the burning rate of propellants greatly, and the burning rate decreases more with a rise in content, but it will increase the pressure exponent. The reason may be that AlN is an inert material, which does not participate in the combustion, while it absorbs the heat generated by the propellant combustion. Moreover, addition of nDPN to the formulation can increase the burning rate and pressure exponent over the low-pressure range, especially when the mass fraction of nDPN is less than $1 \%$; notice that the burning rate could be increased greatly (Figure 9c). 

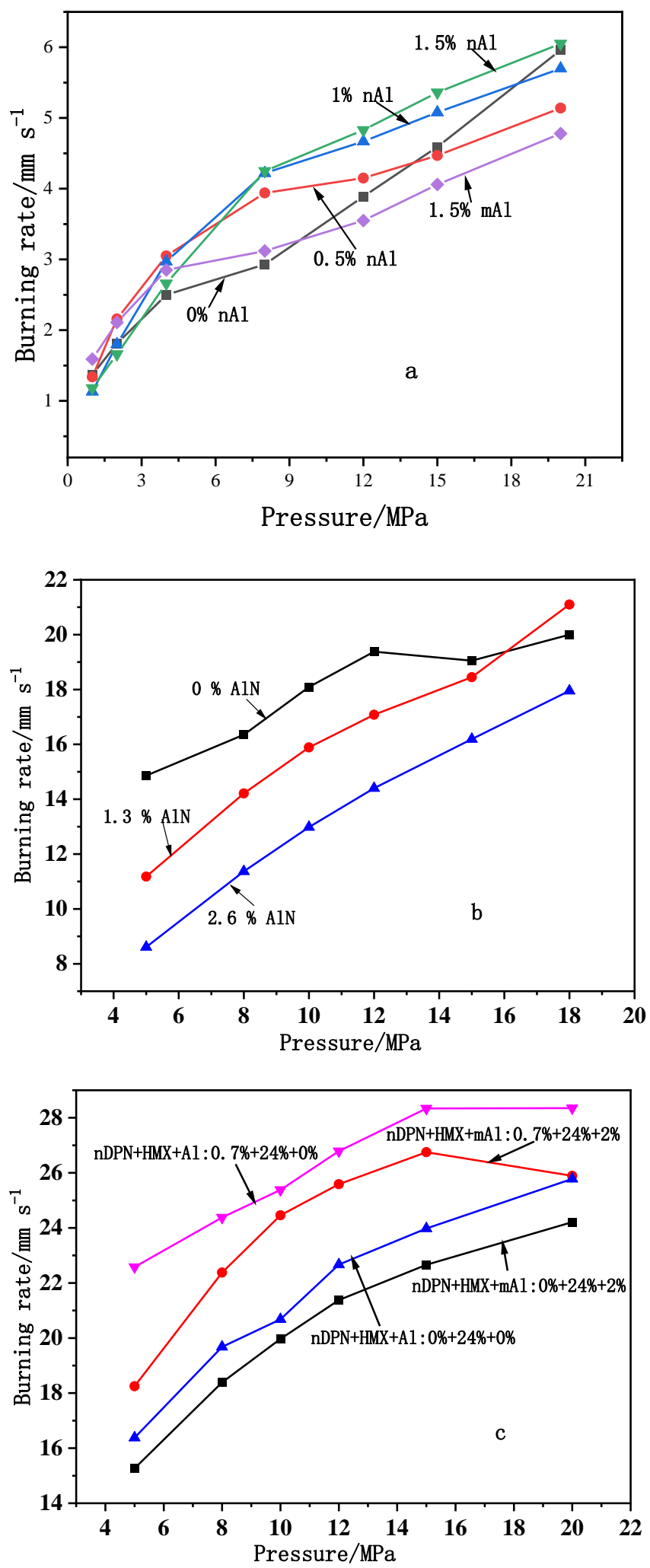

Figure 9. The burning rate vs. pressure curves of RDX-CMDB propellants with different nano powders and contents. (a) $-73.5 \% \mathrm{NG} / \mathrm{NC}+19.5 \%$ burning rate inhibitor $+4.0 \%$ catalyst $+3.0 \%$ additives with and without $\mathrm{nAl} ;(\mathbf{b})-63.0 \% \mathrm{NG} / \mathrm{NC}+2.3 \%$ catalyst $+2.8 \%$ additives $+26 \% \mathrm{RDX}$ $+4.6 \%$ diethyl phthalate $(\mathrm{DEP})+2.6 \%\left(\mathrm{nAl}+\mathrm{Al}_{2} \mathrm{O}_{3}\right)$ with and without $\mathrm{nAlN} ;(\mathrm{c})-63.4 \% \mathrm{NG} / \mathrm{NC}+$ $5.85 \%+4.75 \%$ additives $+24 \%$ HMX with and without $n D P N$. Reproduced from [86], with permission from Chinese Journal of Explosives and Propellants (Huo Zha Yao Xue Bao), 2013. 
Considering all the combustion experiments, $\mathrm{nAl}$ powder, for its many advantages, has significant positive effects on the combustion of solid propellants. Compared to $\mathrm{mAl}$ powder, a large number of spaces exist between the micro-sized particles for its large specific surface area during the process of particles, such as friction or impact. The air absorbed in the space comes into "hot spot" when compressed, and the increasing temperature of the "hot spot" urges the decomposition of condensed AP and the condensed reaction between $\mathrm{AP}$ with nAl powder, until finally, deflagration occurs [87]. From the viewpoint of heat transfer, the addition of $\mathrm{nAl}$ powder in the propellant can effectively increase the heat adsorption in the combustion process. From the viewpoint of dynamics, $\mathrm{nAl}$ powders can contact polymer binder and gaseous reactants because of their large specific surface area. Additionally, the heat release and heat transmission at the combustion surface for $\mathrm{nAl}$ are higher than the values for $\mathrm{mAl}$ at high pressure range [87-89].

\section{Nano Ni (nNi)}

Nickel nanopowder ( $\mathrm{nNi}$ ) has a series of special physical and chemical properties. It is widely used as catalytic material, battery material, cemented carbide material, and magnetic material. It was demonstrated that $\mathrm{nNi}$ has significant catalytic effects on the thermal decomposition characteristics of AP. The exothermic high temperature peak of AP loaded with $5.0 \%$ mass fraction of $\mathrm{nNi}$ is advanced by $105^{\circ} \mathrm{C}$, which is more effective than the addition of micrometric nickel powder $(\mathrm{mNi})$. The scanning electronic microscopy (SEM) images of three nanometric materials are shown in Figure 10. The particles of $\mathrm{nNi}$ were even and globe-shape.

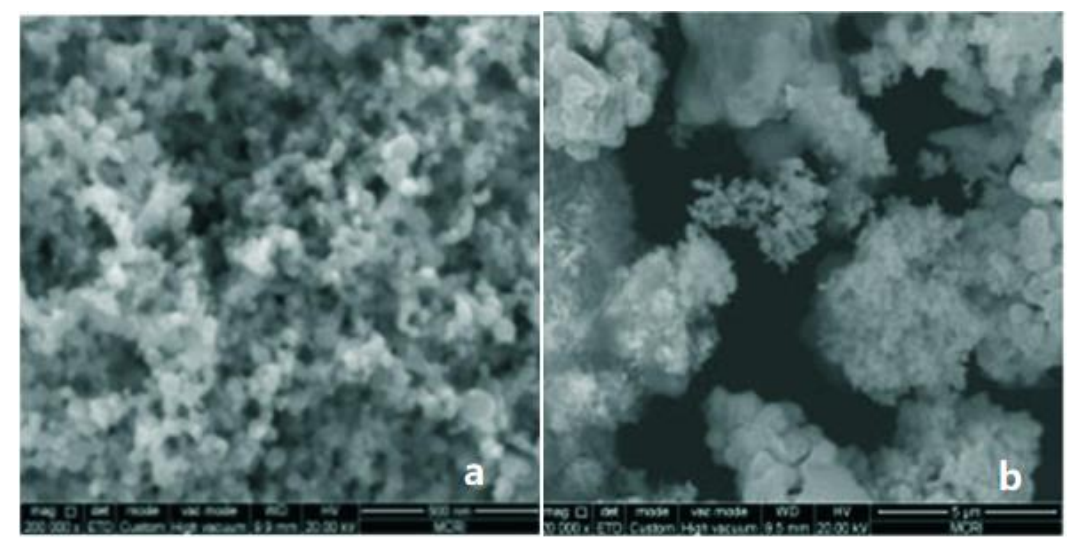

Figure 10. SEM images of several particles. (a) $\mathrm{nNi}$; (b) mNi. Reproduced from [90] with permission from Chinese Journal of Explosives and Propellants (Huo Zha Yao Xue Bao), 2016.

The effects of nNi with $50 \mathrm{~nm}$ diameter on the combustion features of CMDB propellants were explored. It was found that addition of $\mathrm{nNi}$ to the propellant composition could increase the burning rate and reduce the pressure exponent. When adding $0.7 \%$ mass fraction of $\mathrm{nNi}$ to Al-CMDB formulation, the propellant burning rate reaches $35.59 \mathrm{~mm} \cdot \mathrm{s}^{-1}$ at $10 \mathrm{MPa}$, the pressure exponent reduces from 0.43 to 0.17 over the pressure range $8-20 \mathrm{MPa}$, and there is a "mesa effect" at 15-20 MPa. When adding $0.5 \%$ mass fraction of $\mathrm{nNi}$ to CL-20-CMDB formulation, the propellant burning rate increases greatly, and the pressure exponent at 8-20 MPa is 0.1 (Figure 11b). At the same time, the effects of different $\mathrm{nNi}$ mass fractions $(0.2 \%, 0.4 \%, 0.6 \%$ and $0.8 \%)$ on the combustion properties of RDX-CMDB propellant (NC + NG 61\%, RDX $26 \%$, catalyst $4.8 \%$, others $8.2 \%$ ) were investigated and compared to the baseline formulation. It was found that adding $0.2 \% \mathrm{nNi}$ can reduce the burning rates of RDX-CMDB propellant at 2-10 MPa; at $10 \mathrm{MPa}$, the reduction was of $1.26 \mathrm{~mm} \cdot \mathrm{s}^{-1}$. However, the burning rates at 16 and $20 \mathrm{MPa}$ were increased by $0.18 \mathrm{~mm} \cdot \mathrm{s}^{-1}$ and $1.07 \mathrm{~mm} \cdot \mathrm{s}^{-1}$, respectively. With increasing the content of $\mathrm{nNi}$ from $0.2 \%$ to $0.8 \%$, the propellant burning rate increased at $6-16 \mathrm{MPa}$, and a maximum increase was achieved at $10 \mathrm{MPa}$; the propellant burning rate reached the highest value when the mass fraction of 
$\mathrm{nNi}$ was $0.6 \%$. It can be concluded that $\mathrm{nNi}$ has a better effect on enhancing the burning rate at low and middle pressure zone of RDX-CMDB propellant than mNi. Additionally, $\mathrm{nNi}$ can reduce the pressure exponent between 6-16 MPa more effectively than $\mathrm{mNi}$ too (Figure 11c).
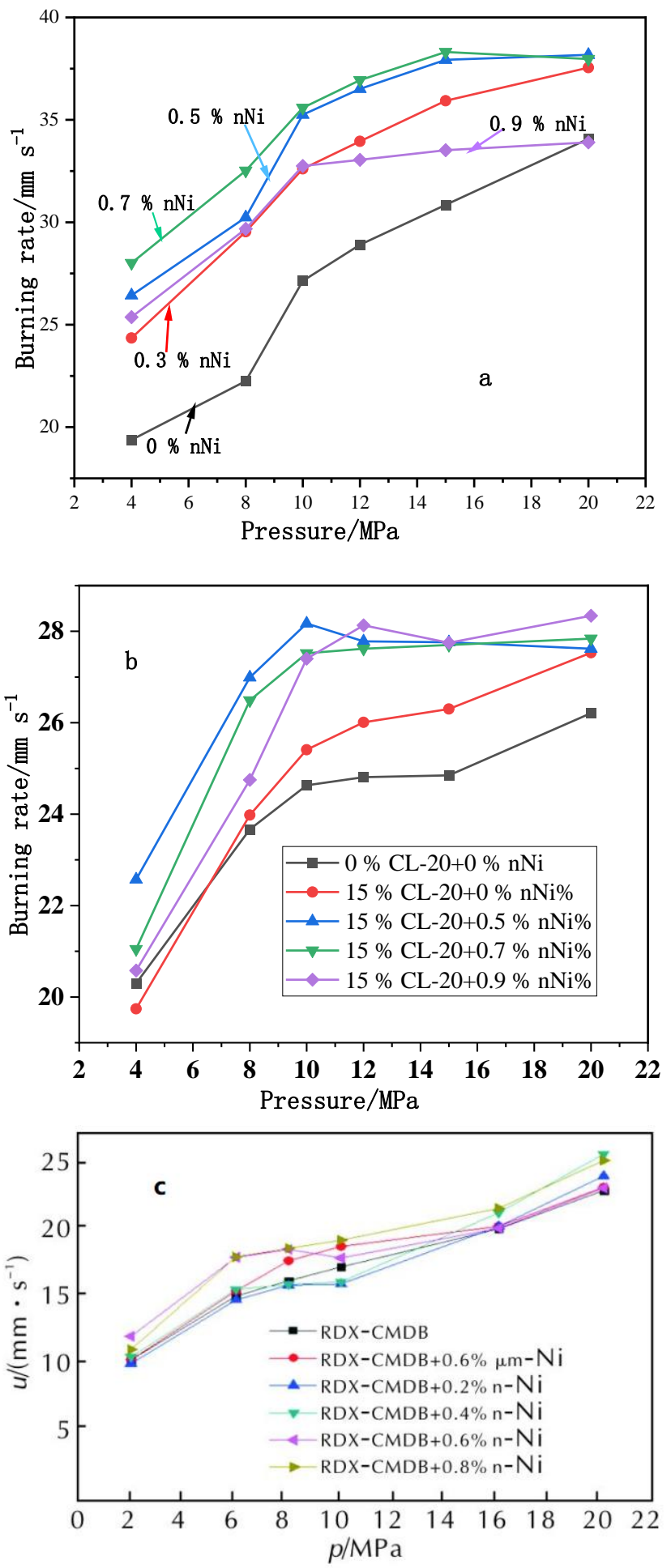

Figure 11. Effect of $\mathrm{nNi}$ on the combustion performance of $\mathrm{CMDB}$ propellants. (a) Formulation with different types of metal nanopowders; (b) CL-20-CMDB propellants formulation with different mass fraction of $\mathrm{nNi}$; (c) RDX-CMDB propellants with different nNi contents. Reproduced from [90,91], with permission from Chinese Journal of Explosives and Propellants (Huo Zha Yao Xue Bao), 2016 and 2019. 
In addition, the effect of nNi on the energetic property, thermal stability, mechanical sensitivity, mechanical performance, inner ballistic properties, and the dependence of burning rate on the aging process of $\mathrm{CMDB}$ propellant $(\mathrm{NC}+\mathrm{NG} / \mathrm{Ct} / \mathrm{Al} / \mathrm{nNi}+\mathrm{RDX}$ + others $=83 / 5.75 / 5.5 / 5.75$ in mass fraction) were studied (Table 1) [92]. Results show that the addition of $\mathrm{nNi}$ can slightly improve the mechanical sensitivity of propellant. After adding $\mathrm{nNi}$, the detonation heat of CMDB propellant decreased by $16 \mathrm{~J} \cdot \mathrm{g}^{-1}$, and the change in specific volume and density was not obvious, while the heat of explosion of propellant with $10 \% \mathrm{RDX}$ and $0.7 \% \mathrm{nNi}$ decreased by $9.0 \mathrm{~J} \cdot \mathrm{g}^{-1}$, and the density decreased by $0.006 \mathrm{~g} \cdot \mathrm{cm}^{-3}$, but the specific volume increased by $12 \mathrm{~L} \cdot \mathrm{kg}^{-1}$.

Table 1. Effect of $\mathrm{nNi}$ on the performance of CMDB propellants.

\begin{tabular}{|c|c|c|c|c|c|}
\hline Samples & $\begin{array}{c}\text { Methyl Violet, } \\
\text { Change Color } \\
\text { Time/Min }\end{array}$ & $\begin{array}{l}\text { Vieri, Change } \\
\text { Color Time/h }\end{array}$ & $\begin{array}{c}5 \mathrm{~h} \text { Explode or } \\
\text { Burn }\end{array}$ & $\begin{array}{c}5 \text { s Outbreak } \\
\text { Temperature } /{ }^{\circ} \mathrm{C}\end{array}$ & $\begin{array}{c}\text { Impact } \\
\text { Sensitivity- } \\
H_{50} / \mathrm{cm}\end{array}$ \\
\hline $\mathrm{RDX} / \mathrm{nNi}$ /others $=0 / 0 / 5.75$ & 68 & 68.0 & not & 268.4 & 10.6 \\
\hline $\mathrm{RDX} / \mathrm{nNi} /$ others $=0 / 0.7 / 5.05$ & 69 & 68.5 & not & 258.0 & 13.7 \\
\hline $\mathrm{RDX} / \mathrm{nNi} /$ others $=10 / 0.7 / 3.55$ & 70 & 68.0 & not & 258.0 & 11.0 \\
\hline Samples & $\begin{array}{c}\text { Friction } \\
\text { sensitivity/\% }\end{array}$ & $\begin{array}{c}\text { Heat of } \\
\text { explosion } / \mathrm{J} \mathrm{g}^{-1}\end{array}$ & $\begin{array}{l}\text { Specific volume/L } \\
\mathrm{kg}^{-1}\end{array}$ & Density $/ \mathrm{g} \mathrm{cm}^{-3}$ & \\
\hline $\mathrm{RDX} / \mathrm{nNi} /$ others $=0 / 0 / 5.75$ & 85 & 4978 & 624 & 1.701 & \\
\hline $\mathrm{RDX} / \mathrm{nNi} /$ others $=0 / 0.7 / 5.05$ & 81 & 4963 & 626 & 1.701 & \\
\hline $\mathrm{RDX} / \mathrm{nNi} /$ others $=10 / 0.7 / 3.55$ & 72 & 4955 & 638 & 1.695 & \\
\hline
\end{tabular}

The effect of nNi on the combustion performance of CMDB propellants with and without aging at different initial temperatures were tested. It was found that the inclusion of $\mathrm{nNi}$ increases the burning rate of Al-CMDB propellant from $28.32 \mathrm{~mm} \cdot \mathrm{s}^{-1}$ to $36.63 \mathrm{~mm} \cdot \mathrm{s}^{-1}$ at $9.81 \mathrm{MPa}$ and lowers the pressure exponent over the pressure range of 12-22 $\mathrm{MPa}$ from 0.26 to 0.12 (Figure 12).

Additionally, the effect of nano metal powders on the burning rate of composite propellant with $60 / 5 / 15 / 20$ mass fraction of $\mathrm{AP} / \mathrm{Al} / \mathrm{HTPB} / \mathrm{RDX}$ was studied. It was found that the addition of $2 \% \mathrm{nNi}$ or the usage of bimodal $\mathrm{Al}$ with a mass ratio of $4: 1 \mathrm{nAl}: \mathrm{mAl}$ or the addition of $2 \% \mathrm{nNi}$ powders can improve the combustion of propellant effectively, while the usage of blending of $1: 1 \mathrm{nAl}: \mathrm{mAl}$ worsens the combustion performance. The ignition threshold and combustion time from the initial particle size to burnout of $\mathrm{nAl}$ and $\mathrm{nNi}$ are lower than that of $\mathrm{mAl}$. Furthermore, $\mathrm{nAl}$ inclined to burn in single mode and $\mathrm{nNi}$ has the greatest influence on the thermal decomposition of AP. The results also confirm the high reactivity of $\mathrm{nAl}$, which leads to a lower reaction temperature and higher degree of reaction ratio as compared with $\mathrm{mAl}$ in air (Figure 13). 

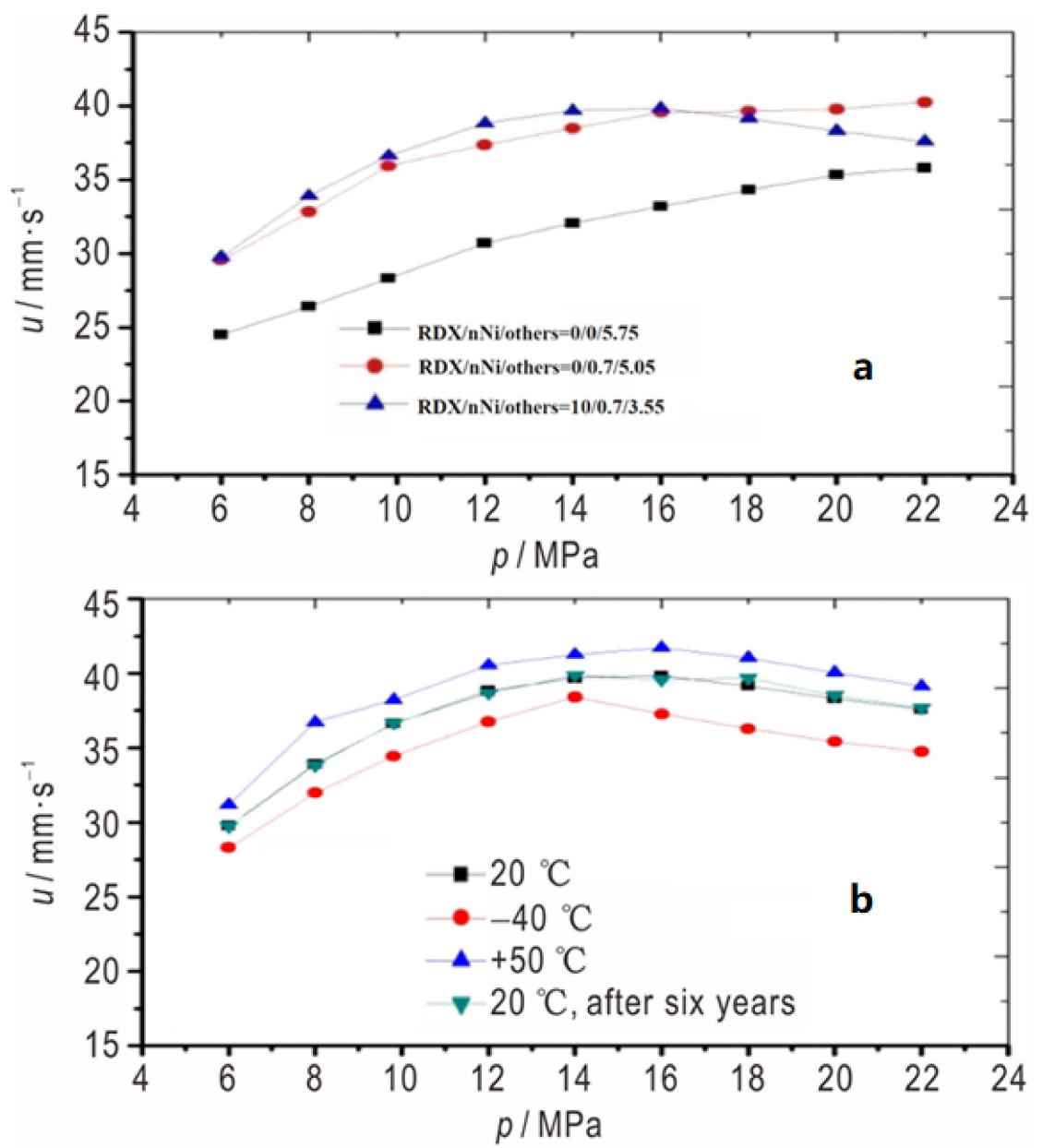

Figure 12. The effect of $\mathrm{nNi}$ on the combustion performance of $\mathrm{CMDB}$ propellants. (a): samples at $20^{\circ} \mathrm{C}$; (b): sample RDX/nNi/others $=10 / 0.7 / 3.55$ at $20{ }^{\circ} \mathrm{C},-40{ }^{\circ} \mathrm{C}, 50{ }^{\circ} \mathrm{C}$, and $20^{\circ} \mathrm{C}$ after six years. Reproduced from [92] with permission from Chinese Journal of Energetic Materials (Han Neng Cai Liao), 2019.

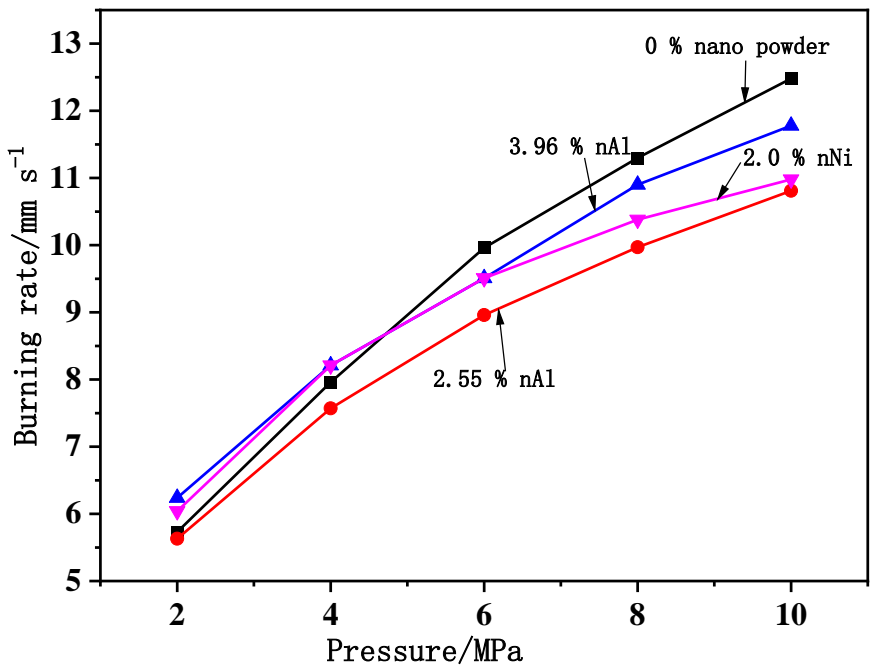

Figure 13. Effect of nano metal powders on the combustion properties of composite propellants. Reproduced from [93] with permission from Journal of Propulsion Technology (Tui Jin Ji Shu), 2004. 


\section{Nano Ti (nTi), Nano Zr (nZr), and More}

The burning rate data of propellants containing different nano-sized particles obtained under different pressures were collected. The effects of different nano metal powders ( $\mathrm{nAl}$, $d_{50}=51 \mathrm{~nm} ; \mathrm{nTi}, d_{50}=83 \mathrm{~nm} ; \mathrm{nZr}, d_{50}=64 \mathrm{~nm}$ ) on the performance of composite propellant (HTPB $/ \mathrm{AP} / \mathrm{Al} /$ Additives $=12 / 71 / 15 / 2$ in mass fraction, with $10 \%$ of $\mathrm{mAl}$ replaced by nano powders) were investigated. It was found that the burning rates of propellant with $\mathrm{nAl}$ powder increase with larger pressures and the increasing extent over the pressure range 1.0-7.0 $\mathrm{MPa}$ is obviously higher than that over the pressure range $7.0-13 \mathrm{MPa}$. The pressure exponent of the nAl formulation is $0.33(1-15 \mathrm{MPa})$, which is the lowest one among the tested samples. Moreover, comparing the samples with and without $\mathrm{nAl}$ powder indicates that the propellant burning rates increase effectively with decreasing size of the metal particles. Furthermore, the density of composite propellants with different nano-sized metal particles is in the range of $1.732-1.784 \mathrm{~g} \cdot \mathrm{cm}^{-3}$, which is larger than that of the propellant with standard $\mathrm{Al}$ powder $\left(1.731 \mathrm{~g} \cdot \mathrm{cm}^{-3}\right)$. Maybe this is the effect of $\mathrm{Al}$ oxide on the surface of $\mathrm{nAl}$. The heat of explosion of composite propellant without $\mathrm{nAl}$ is $6045 \mathrm{~J} \cdot \mathrm{g}^{-1}$, which is higher than that of the samples with $\mathrm{nZr}$ and nTi particles (5793 and $\left.5821 \mathrm{~J} \cdot \mathrm{g}^{-1}\right)$ but lower than that of the sample with nAl particles $\left(6104 \mathrm{~J} \cdot \mathrm{g}^{-1}\right)$. The mechanical sensitivity result reveals that the use of micro-sized powder leads to a decrease in the sensitivities of friction and impact for solid propellants, while the compositions with nano-sized particles show high friction sensitivity and impact sensitivity [94,95].

From the surface image (Figure 14), lots of granulated particles are visible on the surface of the cured composite propellants. The different nano-sized particles are compatible with the ingredients of composite solid propellant systems, and the granulated particles with smaller diameters can sufficiently fill the spaces between the bigger grains.

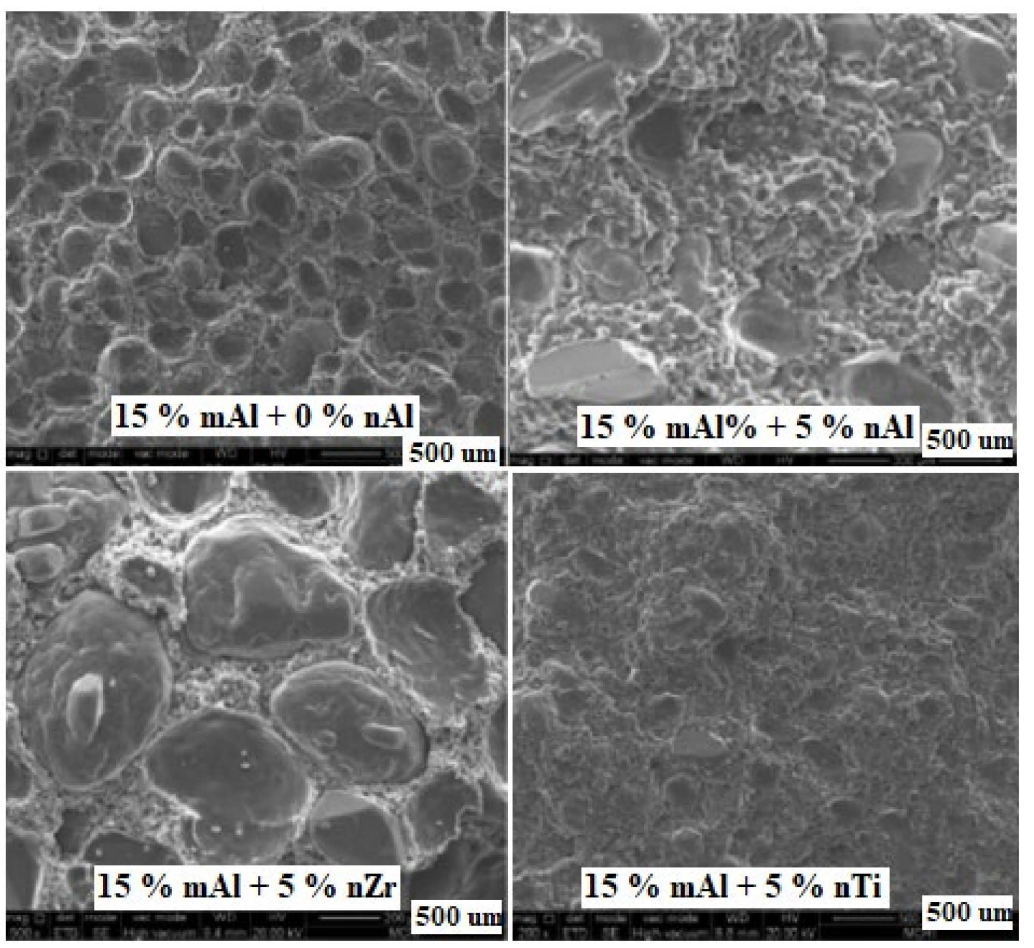

Figure 14. Microstructure surface of composite propellants containing different nano-sized particles. Reproduced from [96], with permission from Wiley, 2014.

For the other nano-sized metal powder, the effect of spherical shaped nano-sized Fe (nFe) with $50 \mathrm{~nm}$ diameter, nano-sized $\mathrm{Co}(\mathrm{nCo})$ with $42 \mathrm{~nm}$ diameter, and nNi with $36 \mathrm{~nm}$ diameter powders on the thermal decomposition of AP and combustion properties of HTPB / AP propellant were investigated [97]. It was found that $2 \%$ content of nCo powder 
reduces the high-temperature decomposition peak of AP by $144.0^{\circ} \mathrm{C}$. When the content of nCo increases to $7 \%$, the high-temperature exothermic peak temperature is advanced by $154.7^{\circ} \mathrm{C}$, but the maximum activation energy is increased by $776 \mathrm{~J} \cdot \mathrm{g}^{-1}$. When the content of $\mathrm{nNi}$ is $5 \%$, the high temperature thermal decomposition peak of AP is reduced by $116.7^{\circ} \mathrm{C}$. When the content of $\mathrm{nFe}$ is $2 \%$, the high temperature thermal decomposition peak temperature of AP is advanced by $103.2^{\circ} \mathrm{C}$. Furthermore, adding nCo powder, the propellant burning rate increases by $18.35 \%$ at $7 \mathrm{MPa}$ and $10.25 \%$ at $10 \mathrm{MPa}$, while the pressure exponent decreases by $17.89 \%$ over the pressure range $5-11 \mathrm{MPa}$. Adding $\mathrm{nFe}$ powder, the propellant burning rate increases by $11.52 \%$ at $7 \mathrm{MPa}$ and $9.20 \%$ at $10 \mathrm{MPa}$, while the pressure exponent decreases by $14.34 \%$ over the pressure range of 5-11 MPa. Adding $\mathrm{nNi}$ powder, the propellant burning rate increases by $5.21 \%$ at $7 \mathrm{MPa}$ and $1.63 \%$ at $10 \mathrm{MPa}$, while the pressure index decreases by $7.34 \%$ over the pressure range of 5-11 $\mathrm{MPa}$.

In summary, to promote the practical applications of nano metals in solid propellants, much investigation needs to be done in the future, such as spheric coating, high-active metal-based composites, active metals, etc. Understanding of these effects opens the path to improved ballistic performance, which will be further investigated. Table 2 summarizes the advantages and disadvantages of the examined nano metals on the performance of energetic compositions.

Table 2. Summary of nano-metric metals and its effects on the performance of energetic compositions.

\begin{tabular}{|c|c|c|c|}
\hline \multicolumn{2}{|c|}{ Types of Metals } & \multirow[t]{2}{*}{ Advantages and Disadvantages } & \multirow{2}{*}{$\begin{array}{l}\text { Refs. } \\
{[26,27]}\end{array}$} \\
\hline $\begin{array}{l}\text { Carbon } \\
\text { coating }\end{array}$ & nAl@C & & \\
\hline \multirow{2}{*}{$\begin{array}{l}\text { Metals } \\
\text { coating }\end{array}$} & nAl@B & $\begin{array}{l}\text { The dispersion feature was improved, the onset oxygen temperature and the heat of } \\
\text { combustion of } \mathrm{Al} \text { were increased. }\end{array}$ & {$[28,29]$} \\
\hline & $\mathrm{nAl} @ \mathrm{Ni}$ & $\begin{array}{l}\text { The stability is good. The active } \mathrm{Al} \text { content changes little after storage for one month } \\
\text { in air. The burning rate of solid propellants increased. }\end{array}$ & {$[31,32]$} \\
\hline \multirow[t]{2}{*}{$\begin{array}{l}\text { Metal oxide } \\
\text { coating }\end{array}$} & $\mathrm{nAl} @ \mathrm{Al}_{2} \mathrm{O}_{3}$ & $\begin{array}{l}\text { The agglomeration of particles reduced; the burning rate of solid propellants increases. } \\
\text { The heat release behavior of nAl hindered, and the oxidation exothermic temperature } \\
\text { increased. The active } \mathrm{Al} \text { content reduced. }\end{array}$ & [34] \\
\hline & nAl@CuO & with high reactivity and quick reactive speed. & [35-38] \\
\hline \multirow{4}{*}{$\begin{array}{l}\text { Organic } \\
\text { acid coating }\end{array}$} & nAl@OA & $\begin{array}{l}\text { The exothermic peak temperature moved forward, the stability towards oxidation in } \\
\text { air and in water increased. }\end{array}$ & [40-42] \\
\hline & nAl@SA & $\begin{array}{l}\text { The combustion performance is more complete, the stability towards oxidation in air } \\
\text { and in water increased. }\end{array}$ & {$[43]$} \\
\hline & nAl@PA & The active $\mathrm{Al}$ content decreased & {$[21,46]$} \\
\hline & nAl@FS & $\begin{array}{l}\text { The dispersity was improved, and the particle size distribution was more } \\
\text { homogeneous. The ignition delay time is shorter, and the combustion reaction is more } \\
\text { intense, the flame brightness is higher. }\end{array}$ & [47] \\
\hline \multirow{2}{*}{$\begin{array}{l}\text { Polymer } \\
\text { coating }\end{array}$} & $\begin{array}{l}\text { nAl@GAP } \\
\mathrm{nAl} @ H T P B\end{array}$ & $\begin{array}{l}\text { The core-shell particles are observed, while the decomposition temperature increases. } \\
\text { The active Al content is less than } 50 \% \text {. }\end{array}$ & $\begin{array}{c}{[49,50]} \\
{[51]}\end{array}$ \\
\hline & $\mathrm{nAl} @ \mathrm{NC}$ & $\begin{array}{l}\text { The stability to oxidation in air during the storage period increased, the reactivity by } \\
\text { heating is high. }\end{array}$ & {$[52]$} \\
\hline $\begin{array}{l}\text { Energetic } \\
\text { materials } \\
\text { coating }\end{array}$ & nAl@RDX & $\begin{array}{l}\text { The performance of } \mathrm{Al} \text { in propellants improved; the activation energy reduced. The } \\
\text { active } \mathrm{Al} \text { content is up to } 89 \% \text {. }\end{array}$ & [53] \\
\hline \multirow{4}{*}{$\begin{array}{l}\text { Fluoride } \\
\text { coating }\end{array}$} & nAl@F & $\begin{array}{l}\text { The active } \mathrm{Al} \text { content is up to } 85.85 \% \text {, the combustion of } \mathrm{nAl} \text { was promoted, and the } \\
\text { heat of combustion is high. The regression rate of the fuel promoted. }\end{array}$ & [54-56] \\
\hline & nAl@PF & $\begin{array}{c}\text { A core-shell structure was observed. The energy amount and energy release rate is } \\
\text { higher than that of nAl. }\end{array}$ & {$[58]$} \\
\hline & nAl@Viton B & $\begin{array}{l}\text { A core-shell structure was observed. The protective effect, the energy amount and } \\
\text { energy release rate is higher than that of nAl. }\end{array}$ & {$[58]$} \\
\hline & nAl@shellac & The energy amount and energy release rate are higher than that of $\mathrm{nAl}$. & [58] \\
\hline
\end{tabular}


Table 2. Cont.

\begin{tabular}{|c|c|c|c|}
\hline \multicolumn{2}{|c|}{ Types of Metals } & Advantages and Disadvantages & Refs. \\
\hline \multirow{5}{*}{$\begin{array}{l}\text { Other } \\
\text { materials } \\
\text { coating }\end{array}$} & nAl@AP & The ignition temperature is lower than that of $\mathrm{nAl}$. & {$[59,60]$} \\
\hline & nAl@DOS & The active $\mathrm{Al}$ content is low. & [61] \\
\hline & nAl@PDA & The crystal form of $\mathrm{Al}$ remains unchanged before and after coating. & [62] \\
\hline & nAl@NDZ & $\begin{array}{l}\text { The active } \mathrm{Al} \text { content and heat of explosive decreased. The burning rate of propellant } \\
\text { increased, while the pressure exponent decreased. }\end{array}$ & [63] \\
\hline & nAl@NGTC & $\begin{array}{l}\text { The active } \mathrm{Al} \text { content and heat of explosive decreased. The burning rate of propellant } \\
\text { increased, while the pressure exponent decreased. }\end{array}$ & [63] \\
\hline \multicolumn{2}{|r|}{$\mathrm{nNi}$} & $\begin{array}{l}\text { Addition of } \mathrm{nNi} \text { to the propellant increases the burning rate and reduce the pressure } \\
\text { exponent. Addition of nNi can slightly increase the mechanical sensitivity of } \\
\text { propellant. The detonation heat, the heat of explosion and density of CMDB } \\
\text { propellant decreased, while the specific volume increased. }\end{array}$ & [90-92] \\
\hline \multicolumn{2}{|r|}{$\mathrm{nTi}$} & The heat of explosion of propellant decreased, while the density increased. & [94-96] \\
\hline \multicolumn{2}{|r|}{$\mathrm{nZr}$} & The heat of explosion of propellant decreased, while the density increased. & [94-96] \\
\hline \multicolumn{2}{|r|}{$\mathrm{nFe}$} & $\begin{array}{l}\text { The high temperature thermal decomposition peak temperature of AP is advanced, } \\
\text { the propellant burning rate increases, while pressure exponent decreases. }\end{array}$ & [97] \\
\hline \multicolumn{2}{|r|}{ nCo } & $\begin{array}{l}\text { Addition of } \mathrm{nCo} \text { reduces the high-temperature decomposition peak of } \mathrm{AP} \text {, the } \\
\text { propellant burning rate increases, but the maximum activation energy and pressure } \\
\text { exponent decreased. }\end{array}$ & [97] \\
\hline
\end{tabular}

\section{Prospects and Future Trends of Metal Nanopowders}

For Al nanopowders, the steady burning rates are not affected by particles in the micrometric range (Brunauer-Emmett-Teller (BET) $\leq 2 \mathrm{~m}^{2} \mathrm{~g}^{-1}$ ) but strongly increased by decreasing size particles over the explored nanometric range; for very small particles, the appreciable decrease in active metal hinders a further increase in steady burning rate. Pressure exponents showed only minor changes within the limits of strand burner experiments conducted under standard operating conditions. Additionally, for ignition, an appreciable decrease is found for $\mathrm{nAl}$ particles in the range $0.1-0.2 \mu \mathrm{m}$, while little effect was observed for $\mu \mathrm{Al}$. The minute $\mathrm{nAl}$ powder manifest a strong reactivity mainly due to their increased specific surface, notwithstanding the simultaneous decrease in active $\mathrm{Al}$ content (typically, from $99.6 \%$ of $17 \mu \mathrm{m} \mathrm{Al}$ to $88.2 \%$ for nAl produced by electrical explosion of wires) [98]. Within the current rocket propulsion technology, ultrafine particles, such as in the range $50-150 \mathrm{~nm}$, are preferable to true nanosized particles. Maybe this will change in the future, but not in the short term [99].

Even if the $2 \mathrm{P}$ losses are mitigated, nanosized energetic ingredients with higher energy densities and faster energy release rates exhibited with respect to conventional ingredients arose great expectations in solid propulsion, but despite the intense worldwide investigation programs, use of $\mathrm{nAl}$ still today also entails several negative effects. Loss of active metal, clustering during manufacture and storage, EOM viscosity, possible impairment of mechanical properties, less effective acoustic damping, aging, and cost (even though it is nowadays much diminished) are more than enough to balance the expected advantages. Moreover, with increasing $\mathrm{nAl}$ fraction, friction sensitivity, impact sensitivity, but also the measured heat of combustion (because of higher combustion efficiency), all increase [96,99-101]. The recommended approach to get the best of both worlds is to resort to dual metallic fuels, properly blending $\mu \mathrm{Al}$ and $\mathrm{nAl}$. Another approach to exploit the potential of $\mathrm{nAl}$ is particle coating, the complexities of which, however, require careful manufacturing and do not lead to immediate solutions [98]. Additionally, mostly laboratory level applications of metal nanopowders are reported and often for scientific purposes only. A number of practical reasons prevent the applications at industrial level, such as particles coating with inert materials, cost, aging, etc. A good control of particle size, metal content, and dispersion is a crucial requirement for applications of nanoingredients in propulsion. 


\section{Conclusions}

Metal nanoparticles have wide application aspects in various explosives and propulsion systems, including advanced components of pyrotechnic compositions, effective burning rate modifiers of solid propellants, etc. Based on the investigations, the following conclusions can be drawn:

(1) Addition of $\mathrm{nAl}$ is beneficial to improve the burning rate and possibly reduce the burning rate pressure exponent, but at the same time, the low active $\mathrm{Al}$ content of $\mathrm{nAl}$ powder leads to a reduction the heat of explosion of propellants.

(2) A core-shell structure of nanoparticles can be obtained, and the burning rate of solid propellants can be increased using different material coatings on the surface of $\mathrm{nAl}$. The addition of $\mathrm{nTi}, \mathrm{nZr}$ can increase the density of propellant, while the heat of explosion of propellant decreases.

(3) Within the current rocket propulsion technology, mostly laboratory level applications of metal nanopowders are reported and often for scientific purposes; much work is needed for the applications of metal nanopowders at an industrial level.

Author Contributions: Conceptualization, W.P. and D.L.; resources, W.P., H.X., Y.L. and X.L.; data curation, W.P. and Y.L.; writing-original draft preparation, W.P. and Y.L.; writing-review and editing, L.T.D.; project administration, X.F.; funding acquisition, W.P, Z.Q. All authors have read and agreed to the published version of the manuscript.

Funding: This research was funded by "Science and Technology on Combustion and Explosion Laboratory Foundation of China, grant number 2019SYSZCJJ".

Institutional Review Board Statement: Not applicable.

Informed Consent Statement: Not applicable.

Data Availability Statement: Not applicable.

Acknowledgments: The authors are thankful to colleagues from Analysis and Measurement Center on Energetic Materials and Science and Technology on Combustion and Explosion Laboratory, $\mathrm{Xi}^{\prime}$ an Modern Chemistry Research Institute for the particle micrograph experiments and thermal decomposition tests. We are especially thankful to TaiZhong Huang from Jinan University, China for providing many helpful suggestions and English statements.

Conflicts of Interest: The authors declare no conflict of interest. The funders had no role in the design of the study; in the collection, analyses, or interpretation of data; in the writing of the manuscript; or in the decision to publish the results.

\section{References}

1. He, W.; Liu, P.J.; He, G.Q.; Gozin, M.; Yan, Q.L. Highly reactive metastable intermixed composites (MICs): Preparations and characterizations. Adv. Mater. 2018, 30, 1706293. [CrossRef] [PubMed]

2. Pang, W.Q.; Fan, X.Z.; Zhang, Z.P. Nano-Sized Metal Powder: Preparation, Characterization and Energetic Application; National Defense Industry Press: Beijing, China, 2016.

3. $\quad$ Pang, W.Q.; Fan, X.Z.; Wang, K.; Chao, Y.M.; Xu, H.X.; Qin, Z.; Zhao, F.Q. Al-based nano-sized composite energetic materials (nano-CEMs): Preparation, characterization, and performance. Nanomaterials 2020, 10, 1039. [CrossRef]

4. Kumar, R.; Siril, P.F.; Soni, P. Tuning the particle size and morphology of high energetic material nanocrystals. Def. Technol. 2015, 11, 382-389. [CrossRef]

5. Carole, R. Al-Based Energetic Nano Materials: Design, Manufacturing, Properties and Applications; Wiley: Hoboken, NJ, USA, 2015.

6. Rossi, C. Nano-energetic materials for MEMS: A review. J. Micro Electro Mech. Syst. 2007, 16, 919-931. [CrossRef]

7. Pang, W.Q.; DeLuca, L.T.; Gromov, A.; Cumming, A.S. Innovative Energetic Materials: Properties, Combustion Performance and Application; Springer: Taramani, India, 2020.

8. Zeng, C.C.; Yang, Z.J.; Wen, Y.S.; He, W.; Zhang, J.H.; Wang, J.; Huang, C.; Gong, F.Y. Performance optimization of core-shell HMX@(Al@GAP) aluminized explosives. Chem. Eng. J. 2021, 407, 126360. [CrossRef]

9. Pang, W.Q.; DeLuca, T.L.; Fan, X.Z.; Wang, K.; Li, J.Q.; Zhao, F.Q. Progress on modification of high active aluminum powder and combustion agglomeration in chemical propellants. J. Solid Rocket Technol. 2019, 42, 42-53.

10. Liu, P.A.; Liu, J.P.; Wang, M.J. Ignition and combustion of nano-sized aluminum particles: A reactive molecular dynamics study. Combust. Flame 2019, 201, 276-289. [CrossRef] 
11. DeLisio, B.J.; Hu, X.; Wu, T.; Egan, G.C.; Young, G.; Zachariah, M.R. Probing the reaction mechanism of aluminum/poly(vinylidene fluoride) composites. J. Phys. Chem. B 2016, 120, 5534-5542. [CrossRef] [PubMed]

12. Jiang, Y.; Deng, S.; Hong, S.; Tiwari, S.; Chen, H.; Nomura, K.; Kalia, R.K.; Nakano, A.; Vashishta, P.; Zachariah, M.R.; et al. Synergistically chemical and thermal coupling between graphene oxide and graphene fluoride for enhancing aluminum combustion. ACS Appl. Mater. Interfaces 2020, 12, 7451-7458. [CrossRef] [PubMed]

13. Huang, C.; Yang, Z.; Li, Y.; Zheng, B.; Yan, Q.; Guan, L.; Luo, G.; Li, S.; Nie, F. Incorporation of high explosives into nano-aluminum based microspheres to improve reactivity. Chem. Eng. J. 2020, 383, 123110. [CrossRef]

14. Lefrancois, A.; Legallic, C. Expertise of nanometric aluminium powder on the detonation efficiency of explosives. In Proceedings of the 32nd International Annual Conference of ICT, Virtual, 3-6 July 2001.

15. Jacob, R.J.; Wei, B.; Zachariah, M.R. Quantifying the enhanced combustion characteristics of electrospray assembled aluminum mesoparticles. Combust. Flame 2016, 167, 472-480. [CrossRef]

16. He, W.; Ao, W.; Yang, G.; Yang, Z.; Guo, Z.; Liu, P.J.; Yan, Q.L. Metastable energetic nanocomposites of MOF-activated aluminum featured with multi-level energy releases. Chem. Eng. J. 2020, 381, 122623. [CrossRef]

17. Ma, Z.; Gao, B.; Wu, P.; Facile, S.J. Continuous and large-scale production of coreshell HMX@TATB composites with superior mechanical properties by a spraydrying process. RSC Adv. 2015, 5, 21042-21049. [CrossRef]

18. Lin, C.; Zeng, C.; Wen, Y.; Gong, F.; He, G.; Li, Y.; Yang, Z.; Ding, L.; Li, J.; Guo, S. Litchilike core-shell HMX@HPW@PDA microparticles for polymer-bonded energetic composites with low sensitivity and high mechanical properties. ACS Appl. Mater. Interfaces 2020, 12, 4002-4013. [CrossRef]

19. Gong, F.; Zhang, J.; Ding, L.; Yang, Z.; Liu, X. Mussel-inspired coating of energetic crystals: A compact core-shell structure with highly enhanced thermal stability. Chem. Eng. J. 2017, 309, 140-150. [CrossRef]

20. Zeng, C.; Wang, J.; He, G.; Yang, Z.; Liu, S.; Gong, F. Enhanced water resistance and energy performance of core-shell aluminum nanoparticles via in situ grafting of energetic glycidyl azide polymer. J. Mater. Sci. 2018, 53, 12091-12102. [CrossRef]

21. Pang, W.Q.; DeLuca, L.T.; Xu, H.X.; Fan, X.Z.; Zhao, F.Q.; Liu, Y.F.; Xie, W.X.; Li, H.Y. Effect of nano-metric aluminum powder on the properties of composite solid propellants. Int. J. Energetic Mater. Chem. Propuls. 2015, 14, 265-282. [CrossRef]

22. DeLuca, L.T. Nanoenergetic Ingredients to Augment Solid Rocket Propulsion. In Nanomaterials in Rocket Propulsion Systems; Yan, Q.L., He, G.Q., Liu, P.J., Gozin, M., Eds.; Elsevier: Amsterdam, The Netherlands, 2018.

23. Li, X.H. Preparation and Activity Maintenance of Organic Coated Nano Aluminum Powder; Nanjing Normal University: Nanjing, China, 2017.

24. Ma, X.X.; Li, Y.X.; Hussain, I.; Shen, R.Q.; Yang, G.C.; Zhang, K.L. Core-shell structured nanoenergetic materials: Preparation and fundamental properties. Adv. Mater. 2020, 32, 2001291. [CrossRef] [PubMed]

25. Ruoff, R.S.; Lorents, D.C.; Chan, B.; Malhotra, R.; Subramoney, S. Single crystal metals encapsulated in carbon nanoparticles. Science 1993, 259, 346-348. [CrossRef]

26. Park, K.; Rai, A.; Zachariah, M.R. Characterizing the coating and size-resolved oxidative stability of carbon-coated aluminum nanoparticles by single-panicle mass-spectrometry. J. Nanoparticle Res. 2006, 8, 455-464. [CrossRef]

27. Zhang, X.T.; Song, W.L.; Guo, L.G.; Xie, C.S.; Hu, M.L. Preparation of carbon-coated aluminum nanoparticles. J. Solid Rocket Technol. 2007, 30, 338-342.

28. Spalding, M.J.; Krier, H.; Burton, R.L. Boron suboxides measured during ignition and combustion of boron $\mathrm{m}$ shocked Ar/F/O 2 and $\mathrm{Ar} / \mathrm{N}_{2} / \mathrm{O}_{2}$ mixtures. Combust. Flame 2000, 120, 200-210. [CrossRef]

29. Kwon, Y.S.; Gromov, A.A.; Ilyin, A.P. Reactivity of superfine aluminum powders stabilized by aluminum diboride. Combust. Flame 2002, 131, 349-352. [CrossRef]

30. Klengel, R.; Klengel, S.; Schischka, J.; Lorenz, G.; Petzold, M. Improvement of nickel wire bonding using Al nano coating. In Proceedings of the 5th Electronics System-Integration Technology Conference (ESTC), Helsinki, Finland, 16-18 September 2014.

31. Qiu, H.L.; Yin, G. A Preparation Method of Core Shell Structure Functional Coating Nano Al-Ni Powder. CN200710056768, 13 August 2008.

32. Jiang, Z.; Li, S.F.; Zhao, F.Q.; Liu, Z.R.; Yin, C.M.; Luo, Y.; Li, S.W. Research on the combustion properties of propellants with low content of llano metal powders. Propellants Explos. Pyrotech. 2010, 31, 139-147.

33. Cheng, Z.P.; Yang, Y.; Wang, Y.; Li, M.M.; Li, F.S. Oxidation ability of nanocrystalline Ni-coated Al powders. Acta Phys. Chim. Sin. 2008, 23, 152-156.

34. Jiang, H.C. Comparative Study on Properties of Thermite Composed of Nano Aluminum Powder with Different Particle Sizes; Nanjing University of Science and Technology: Nanjing, China, 2013.

35. Badiola, C.; Schoenitz, M.; Zhu, X.Y.; Dreizin, E.D. Nanocomposite thermite powders prepared by cryomilling. J. Alloys Compd. 2009, 488, 386-391. [CrossRef]

36. Tillotson, T.M.; Gash, A.E.; Simpson, R.L.; Hrubesh, L.W.; Poco, J.F. Nanostructured energetic materials using sol-gel methodologies. J. Non-Cryst. Solids 2001, 285, 338-345. [CrossRef]

37. Schoenitz, M.; Umbrajkar, S.M.; Dreizin, E.L. Kinetic analysis of thermite reactions in $\mathrm{Al}-\mathrm{MoO}_{3}$ nanocomposites. J. Propuls. Power 2015, 23, 683-687. [CrossRef]

38. Xu, D.G.; Yang, Y.; Cheng, H.; Li, Y.Y.; Zhang, K.L. Integration of nano-A1 with $\mathrm{Co}_{3} \mathrm{O}_{4}$, nanorods to realize high-exothermic core-shell nanoenergetic materials on a silicon substrate. Combust. Flame 2012, 159, 2202-2209. [CrossRef] 
39. Lewis, W.K.; Rosenberger, A.T.; Gord, J.R.; Crouse, C.A.; Harruff, B.A.; Fernando, K.A.S.; Smith, M.J.; Phelps, D.K.; Spowart, J.E.; Guliants, E.A.; et al. Multispectroscopic (FTIR, XPS, and TOFMS-TPD) investigation of the core-shell bonding in sonochemically prepared aluminum nanoparticles capped with oleic acid. J. Phys. Chem. C 2010, 114, 6377-6380. [CrossRef]

40. Yu, Q.Q.; Qiao, Z.W.; Ma, S.H. Research progress of nano aluminum powder surface coating modification and active aluminum analysis. Conteporary Chem. Ind. 2020, 49, 2306-2309.

41. Femando, K.A.S.; Smith, M.J.; Harruff, B.A.; Lewis, W.K.; Guliants, E.A.; Bunker, C.E. Sonochemically Assisted Thermal Decomposition of Alane N,N-Dimethylethylamine with Titanium (IV) Isopropoxide in the Presence of Oleic Acid to Yield Air-Stable and Size-Selective Aluminum CoreShell Nanoparticles; Elsevier: Amsterdam, The Netherlands, 2009.

42. Yao, E.G.; Zhao, F.Q.; Gao, H.X.; Xu, S.Y.; Hu, R.Z.; Hao, H.X.; An, T.; Pei, Q.; Xiao, L.B. Thermal behavior and non-isothermal decomposition reaction kinetics of aluminum nanopowders coated with an oleic acid/Hexogen composite system. Acta Phys.Chim. Sin. 2012, 28, 781-786.

43. Du, T.K.; Zhu, B.Z.; Li, H.; Liu, Y.W.; Sun, Y.L. Combustion characterization of nano-aluminum coated by stearic acid. J. Anhui Univ. Technol. Nat. Sci. 2016, 33, 23-27.

44. Gromov, A.A.; Förter-Barth, U.; Teipel, U. Aluminum nanopowders produced by electrical explosion of wires and passivated by non-inert coatings: Characterisation and reactivity with air and water. Powder Technol. 2006, 164, 111-115. [CrossRef]

45. Gromov, A.A.; Ilyin, A.; Förter-Barth, U.; Teipel, U. Characterization of aluminum powders: II. Aluminum nanopowders passivated by non-inert coatings. Propellants Explos. Pyrotech. 2006, 31, 401-409. [CrossRef]

46. Liu, T.; Shao, H.; Li, X. Synthesis of Fe-A1 nanopart Mes by hydrogen plasma-metal reaction. J. Phys. Condens. Matter. 2003, 15, 2507. [CrossRef]

47. Yao, E.G.; Zhao, F.Q.; Hao, H.X.; Xu, S.Y.; Gao, H.X.; Li, X. Preparation of aluminum nanopowders coated with perfluorotetradecanoic acid and its ignition and combustion characteristics. Chin. J. Explos. Propellants 2012, 35, 70-75.

48. Bocanegra, P.E.; Chauveau, C.; Gökalp, I. Experimental studies on the burning of coated and uncoated micro and nano-sized aluminum particles. Aerosp. Sci. Technol. 2007, 11, 33-38. [CrossRef]

49. Li, X.L.; Zhao, F.Q.; Gao, H.X.; Yao, E.G.; Yi, J.H.; An, T.; Hao, H.X.; Tan, Y. Preparation, characterization and effects on thermal decomposition of ADN of nano Al/GAP composite particles. J. Propuls. Technol. 2014, 5, 694-700.

50. Zeng, C.C.; Gong, F.Y.; Liu, S.J. Effect of Al@GAP composite particles on thermal decomposition performance of LLM-105. Chin. J. Explos. Propellants 2017, 40, 27-32.

51. Vorozhtsov, A.B.; DeLuca, L.T.; Reina, A.; Lerner, M.I. Effects of HTPB-coating on nano-sized aluminum. Sci. Technol. Energ. Mater. 2015, 76, 105-109.

52. Kwon, Y.S.; Gromov, A.A.; Strokova, J.I. Passivation of the surface of aluminum nanopowders by protective coatings of the different chemical origin. Appl. Surf. Sci. 2007, 253, 5558-5564. [CrossRef]

53. Ma, Z.Y.; Zhao, F.Q.; Xu, J.; Xu, S.Y.; Xiao, L.B.; Yi, J.H.; Cha, M.X. A preparation Method of Energetic Nano Al/RDX Core-Shell Composite Particles. CN103182505A, 3 July 2013.

54. Gany, A. Thermodynamic limitation on boron energy realization in ramjet propulsion. Acta Astronaut. 2014, 98, 128-132. [CrossRef]

55. Dubois, C.; Lafleur, P.G.; Roy, C.; Brousseau, P.; Stowe, R.A. Polymer grafted metal nanoparticles for fuel applications. J. Propuls. Power 2007, 23, 651-658. [CrossRef]

56. Yan, T.; Ren, H.; Ma, A.E.; Jiao, Q.J.; Wang, H.X. Effect of fluororubber coating on the properties of nano-aluminum powders. Acta Armamentarii 2019, 40, 1611-1617.

57. Qin, Z.; Paravan, C.; Colombo, G.; DeLuca, L.T.; Shen, R.Q.; Ye, Y.H. Effect of fluorides coated nano-aluminum powder on combustion properties of HTPB based fuels. Chin. J. Explos. Propellants 2014, 37, 61-65.

58. Ye, M.Q.; Zhang, S.T.; Liu, S.S.; Han, A.J.; Chen, X. Preparation and characterization of pyrotechnics binder-coated nano-aluminum composite particles. J. Energ. Mater. 2017, 35, 300-313. [CrossRef]

59. Wang, T. Thermal Reaction Characteristics and Reaction Kinetics of Coated Nano Aluminum Powder in Carbon Dioxide Atmosphere; Anhui University of Technology: Hefei, China, 2016.

60. Wang, Q.C.; Zhu, B.Z.; Sun, Y.L.; Wang, T. Thermal reaction characteristics and ignition combustion characteristics of nanoaluminum powder Coated with ammonium perchlorate in carbon dioxide. Chin. J. Process Eng. 2017, 17, $271-277$.

61. Tan, C.D. Research on Equipment and Process of Organic Coated Nano Aluminum Powder; Huazhong University of Science and Technology: Wuhan, China, 2012.

62. Xiao, C.; Zhu, Q.; Xie, J. PDA coated aluminum powder and its dispersion stability in HTPB. J. Explos. Explos. $2017,40,60-63$.

63. Gao, D.L.; Zhang, W.; Zhu, H.; Liu, X.C. Application of nano-aluminum in composite propellant. J. Solid Rocket Technol. 2007, 30, $420-423$.

64. Lv, J. Study on Determination Method of Elemental Aluminum Content in Nano Aluminum Powder; Huazhong University of Science and Technology: Wuhan, China, 2009.

65. Duan, H. Study on Activity Characterization Methods of Aluminum Nanoparticles; Huazhong University of Science and Technology: Wuhan, China, 2008.

66. Fedotova, T.D.; Glotov, O.G.; Zarko, V.E. Chemical analysis of aluminum as a propellant ingredient and determination of aluminum and aluminum nitride in condensed combustion products. Propellants Explos. Pyrotech. 2000, 25, 325-332. [CrossRef] 
67. Chen, L. Establishment of Activity Evaluation Method of Nano Aluminum Powder and Research on Additional Energy Storage; Huazhong University of Science and Technology: Wuhan, China, 2009.

68. Yao, E.G.; Zhao, F.Q.; An, T.; Gao, H.X.; Hao, H.X.; Pei, Q. Progress on evaluation methods of the activity of Al nanopowders. J. Solid Rocket Technol. 2011, 34, 603-608.

69. Kim, K. High energy pulsed plasma arc synthesis and material characteristics of nanosized aluminum powder. Met. Mater. Int. 2008, 14, 707-711. [CrossRef]

70. Sun, J.; Simon, S.L. The melting behavior of aluminum nanoparticles. Thermochim. Acta 2007, 463, 32-40. [CrossRef]

71. Guo, L.G. Preparation of Core/Shell Structure Nano Aluminum Powder and Study on Its Activity Change Law; Huazhong University of Science and Technology: Wuhan, China, 2008.

72. Zeng, L.; Jiao, Q.J.; Ren, H.; Zhou, Q. Effect of particle size of nano-aluminum powder on oxide film thickness and active aluminum content. Chin. J. Explos. Propellants 2011, 34, 26-29.

73. Wang, J.K.; Chen, J.; Sun, H.L.; Yu, Q.; Yang, X.L.; Suo, Z.R.; Sun, J.; Yin, Y. Review on micro-nano aluminum oxidation kinetics. Chin. J. Energetic Mater. 2021, 29, 251-266.

74. Gromov, A.A.; Strokova, Y.I.; Ditts, A.A. Passivation films on particles of electro explosion aluminum nanopowders: A review. Russ. J. Phys. Chem. B 2010, 4, 156-169. [CrossRef]

75. He, L.R.; Xiao, L.Q.; Ding, H.Q.; Zhou, W.L. TG-DSC research of shell's effect on activity of nano-aluminum powder. Ordnance Mater. Sci. Eng. 2013, 36, 21-25.

76. He, L.R.; Xiao, L.Q.; Jian, X.X.; Zhou, W.L. Investigation on nano-aluminum thermal reactivity by TG-DSC. J. Solid Rocket Technol. 2011, 34, 628-631.

77. Ke, X.; Guo, S.F.; Gou, B.W.; Wang, N.; Zhou, X.; Xiao, L.; Hao, G.Z.; Jiang, W. Superhydrophobic fluorine-containing protective coating to endow $\mathrm{Al}$ nanoparticles with long-term storage stability and self-activation reaction capability. Adv. Mater. Interfaces 2019, 6, 1901025. [CrossRef]

78. Van Devener, B.; Perez, J.P.L.; Jankovich, J.; Anderson, S.L. Oxidefree, catalyst-coated, fuel-soluble, air-stable boron nanopowder as combined combustion catalyst and high energy density fuel. Energy Fuels 2009, 23, 6111-6120. [CrossRef]

79. Zhang, B.; Huang, C.; Yan, S.; Li, Y.; Cheng, Y. Enhanced reactivity of boron, through adding nano-aluminum and wet ball milling. Appl. Surf. Sci. 2013, 286, 91-98. [CrossRef]

80. Sundaram, D.; Yang, V.; Yetter, R.A. Metal-based nanoenergetic materials: Synthesis, properties, and applications. Prog. Energy Combust. Sci. 2017, 61, 293-365. [CrossRef]

81. DeLuca, L.T.; Marchesi, E.; Spreafico, M.; Reina, A.; Maggi, F.; Rossettini, L.; Bandera, A.; Colombo, G.; Kosowski, B.M. Aggregation vs. agglomeration in metallized solid rocket propellants. Int. J. Energetic Mater. Chem. Propuls. 2010, 10, 91-105. [CrossRef]

82. Sun, Y.L.; Li, S.F. Combustion characteristics of coated nano aluminum in composite propellants. Def. Sci. J. 2006, 56, 543-550. [CrossRef]

83. Dillier, C.A.M.; Demko, A.R.; Thomas, J.C.; Grossman, K.; Seal, S.; Petersen, E.L. Performance of Aluminum-Coated Nano-Sized Boron Additives in AP/HTPB Propellants. In Proceedings of the Spring Technical Meeting of the Central States Section of The Combustion Institute, Minneapolis, MN, USA, 20-22 May 2018.

84. Pang, W.Q.; Fan, X.Z.; Zhao, F.Q.; Xu, H.X.; Zhang, W.; Yu, H.J.; Li, Y.H.; Liu, F.L.; Xie, W.X.; Yan, N. Effects of different metal fuels on the characteristics of HTPB-based fuel-rich solid propellants. Propellants Explos. Pyrotech. 2013, 38, 482-486. [CrossRef]

85. Zhang, W.; Xie, W.X.; Fan, X.Z.; Liu, F.L.; Pang, W.Q.; Yan, N.; Liu, Q. Effects of nano-aluminum on combusiton characteristic of low smoke NEPE propellants. J. Solid Rocket Technol. 2014, 37, 516-520.

86. Yang, Z.F.; Wang, J.N.; Zhang, C.; Zheng, W.; Chen, N.; Zhang, J.; Pi, W.F. Effects of nano-materials on combustion properties of DB and CMDB propellants. Chin. J. Explos. Propellants 2013, 36, 69-72.

87. Altman, I. Burn time of metal nanoparticles. Materials 2019, 12, 1368. [CrossRef]

88. Hill, K.J.; Pantoya, M.L.; Washburn, E.; Kalman, J. Single particle combustion of pre-stressed aluminum. Materials 2019, $12,1737$. [CrossRef]

89. Weiser, V.; Eisenreich, N.; Kelzenberg, S. Influence of the metal particle size on ignition and combustion of energetic materials. In Proceedings of the 32nd Annual conference of ICT, Karlsruhe, Germany, 3-6 July 2001.

90. Yuan, Z.F.; Zhao, F.Q.; Zhang, J.Q.; Song, X.D.; Gao, H.X.; Zheng, W.; Wang, Y.; Pei, J.F.; Wang, J. Effect of nano-nickel powder on combustion properties of Al-CMDB and CL-20-CMDB propellants. Chin. J. Explos. Propellants 2016, 39, 99-103.

91. Yuan, Z.F.; Yang, Y.J.; Zhao, F.Q.; Zhang, J.Q.; Song, X.D.; Gao, H.X.; Xu, S.Y. Effects of different content of nanomaterials on the combustion performance of RDX-CMDB propellants. Chin. J. Explos. Propellants 2019, 42, 566-571.

92. Yuan, Z.F.; Li, J.Q.; Shu, H.M.; Zhang, J.Q.; Song, X.D.; Gao, H.X.; Zhao, F.Q. Effect of nano-Ni on overall properties of Al-CMDB and RDX/Al-CMDB propellants. Chin. J. Energetic Mater. 2019, 27, 729-734.

93. Jiang, Z.; Li, S.F.; Zhao, F.Q.; Liu, Z.R.; Yin, C.M.; Luo, Y.; Li, S.W. Effect of nano aluminum and nickel powders on the combustion properties of composite propellant. J. Propuls. Technol. 2004, 25, 368-372.

94. Zohari, N.; Keshavarz, M.H.; Seyedsadjadi, S.A. The advantages and shortcomings of using nano-sized energetic materials. Cent. Eur. J. Energ. Mater. 2013, 10, 135-147.

95. Gany, A. Micro- and nano- scale phenomena of aluminum agglomeration during solid propellant combustion. Eurasian Chem. Technol. J. 2016, 18, 161-170. [CrossRef] 
96. Pang, W.Q.; Fan, X.Z.; Zhao, F.Q.; Zhang, W.; Xu, H.X.; Yu, H.J.; Xie, W.X.; Yan, N.; Liu, F.L. Effects of different nano-metric particles on the properties of composite solid propellants. Propellants Explos. Pyrotech. 2014, 39, 329-336. [CrossRef]

97. Duan, H.Z. Preparation of Nano iron Series Metal Powders and Composite Powders and Their Catalytic Properties for Propellants. Ph.D. Thesis, Nanjing University of Technology, Nanjing, China, June 2008.

98. DeLuca, L.T.; Galfetti, L.; Maggi, F.; Colombo, G.; Paravan, C.; Reina, A.; Dossi, S.; Fassina, M.; Sossi, A. Characterization and Combustion of Aluminum Nanopowders in Energetic Systems. In Metal Nanopowders: Production, Characterization, and Energetic Applications; Gromov, A., Teipel, U., Eds.; Wiley: Hoboken, NJ, USA, 2014.

99. DeLuca, L.T. Overview of Al-based nanoenergetic ingredients for solid rocket. Def. Technol. 2018, 14, 357-365. [CrossRef]

100. Pang, W.Q.; Zhao, F.Q.; DeLuca, L.T.; Kappenstein, C.; Xu, H.X.; Fan, X.Z. Effects of nanosized Al on the combustion performance of fuel rich solid rocket propellants. Eurasian Chem. Technol. J. 2016, 18, 197-206. [CrossRef]

101. DeLuca, L.T. Nanoaluminum for solid rocket propulsion: Illusions and reality. In Proceedings of the 12th International Symposium on Special Topics in Chemical Propulsion and Energetic Materials (12-ISICP), Santander, Spain, 22-25 March 2021. 